\title{
Kinetics and mechanism of formation of nickel(II)porphyrin and its interaction with DNA in aqueous medium
}

\author{
AHSAN HABIB ${ }^{\mathrm{a}, *}$ (D), SALMA SERNIABAD ${ }^{\mathrm{a}, \mathrm{b}}$, MOHAMMAD SHAMIM KHAN $^{\mathrm{a}}$, \\ ROKAYEA ISLAM ${ }^{\mathrm{a}}$, MRITTIKA CHAKRABORTY ${ }^{\mathrm{a}}$, AKLIMA NARGIS $^{\mathrm{a}}$, \\ MD EMRAN QUAYUM ${ }^{\mathrm{a}}$, MD ASHRAFUL ALAM ${ }^{\mathrm{b}}$, VALENTINA RAPOZZI ${ }^{\mathrm{c}}$ and \\ MASAAKI TABATA ${ }^{\mathrm{d}}$ \\ ${ }^{a}$ Department of Chemistry, Faculty of Science, University of Dhaka, Dhaka 1000, Bangladesh \\ ${ }^{b}$ Department of Applied Chemistry and Chemical Engineering, Noakhali Science and Technology \\ University, Noakhali 3814, Bangladesh \\ ${ }^{\mathrm{c}}$ Department of Medicine, Udine University, P.le Kolbe 4, 33100 Udine, Italy \\ ${ }^{\mathrm{d}}$ Department of Chemistry, Faculty of Science and Engineering, Saga University, 1, Honjo-machi, \\ Saga 840-8502, Japan \\ E-mail: habibchem@du.ac.bd
}

MS received 30 April 2021; revised 24 May 2021; accepted 25 May 2021

\begin{abstract}
Kinetics between 5,10,15,20-tetrakis(N-methylpyridium-4-yl)porphyrin and $\mathrm{Ni}^{2+}$ species were investigated in aqueous solution at $25 \pm 1{ }^{\circ} \mathrm{C}$ in $I=0.10 \mathrm{M}\left(\mathrm{NaNO}_{3}\right)$. Speciation of $\mathrm{Ni}^{2+}$ was done in $I=0.10$ $\mathrm{M}\left(\mathrm{NaNO}_{3}\right)$ for knowing distribution of $\mathrm{Ni}^{2+}$ species with solution $\mathrm{pH}$. Experimental data were compared with speciation diagram constructed from the values of hydrolysis constants of $\mathrm{Ni}^{2+}$ ion. Speciation data showed that hexaaquanickel(II) ions took place in hydrolysis reactions through formation of $\left[\mathrm{Ni}\left(\mathrm{OH}_{2}\right)_{6}\right.$ $\left.{ }_{\mathrm{n}}(\mathrm{OH})_{\mathrm{n}}\right]^{2-\mathrm{n}}$ species with solution $\mathrm{pH}$. According to speciation of $\mathrm{Ni}^{2+}$ and $\mathrm{pH}$ dependent rate constants, rate expression can be written as: $\mathrm{d}\left[\mathrm{Ni}\left(\mathrm{TMPyP}^{4+}\right] / \mathrm{dt}=\left(k_{1}\left[\mathrm{Ni}^{2+}{ }_{(\mathrm{aq})}\right]+k_{2}\left[\mathrm{Ni}(\mathrm{OH})^{+}{ }_{(\mathrm{aq})}\right]+k_{3}\left[\mathrm{Ni}(\mathrm{OH})_{2}{ }^{\mathrm{o}}{ }_{(\mathrm{aq})}\right]+\right.\right.$ $\left.k_{4}\left[\mathrm{Ni}(\mathrm{OH})_{3}^{-}(\mathrm{aq})\right]\right)\left[\mathrm{H}_{2} \mathrm{TMPyP}^{4+}\right]$, where $k_{1}, k_{2}, k_{3}$ and $k_{4}$ were found to be $k_{1}=(0.62 \pm 0.22) \times 10^{-2} ; k_{2}=(3.60$ $\pm 0.40) \times 10^{-2} ; k_{3}=(2.09 \pm 0.52) \times 10^{-2}, k_{4}=(0.53 \pm 0.04) \times 10^{-2} \mathrm{M}^{-1} \mathrm{~s}^{-1}$ at $25 \pm 1{ }^{\circ} \mathrm{C}$, respectively. Formation of hydrogen bonding between $\left[\mathrm{Ni}\left(\mathrm{H}_{2} \mathrm{O}\right)_{5}(\mathrm{OH})\right]^{+}$and $\left[\mathrm{H}_{2} \mathrm{TMPyP}\right]^{4+}$ causes enhanced reactivity. Rate of formation of $[\mathrm{Ni}(\mathrm{II}) \mathrm{TMPyP}]^{4+}$ complex was to be $3.99 \times 10^{-2} \mathrm{M}^{-1} \mathrm{~s}^{-1}$ in $I=0.10 \mathrm{M}, \mathrm{NaNO}_{3}(25 \pm$ $\left.1{ }^{\circ} \mathrm{C}\right)$. UV-Vis and fluorescence data suggested that $[\mathrm{Ni}(\mathrm{II}) \mathrm{TMPyP}]^{4+}$ and $\left[\mathrm{H}_{2}(\mathrm{TMPyP})\right]^{4+}$ interact with DNA via outside binding with self-stacking and intercalation, respectively.
\end{abstract}

Keywords. Speciation of $\mathrm{Ni}^{2+}$; kinetics and mechanism; hydrogen bonding; 5,10,15,20-tetrakis(Nmethylpyridium-4-yl)porphyrinatonickel(II) tetracation; outside binding; chemotherapeutic agents.

\section{Introduction}

Substantial studies by many research groups have been carried out on kinetics and mechanism of formation of metalloporphyrins because of their possible applications as therapeutic agents in medical and biological fields. ${ }^{1-19}$ The structural similarity of the porphyrins with chlorophylls, green pigments of leaves, has also been attracted by researchers for their potential use in an artificial photosynthetic system..$^{20}$ In the human body system, the protoporphyrin IX ring is continuously synthesized during biosynthesis of heme, and iron(II) is subsequently coordinated to the porphyrin core. Studies of the kinetics of incorporation of metal ions into the porphyrins' core provide the mechanistic pathways of the formation of metalloporphyrins. By knowing proper reaction pathways of the formation of metalloporphyrins, it may possible to formulate porphyrin-based new drugs. Hambright and Chock (1974) proposed a general mechanism of formation of metalloporphyrins for the first time, and later that was reviewed by a number of research

\footnotetext{
*For correspondence

Supplementary Information: The online version contains supplementary material available at https://doi.org/10.1007/s12039-02101945-y.
} 
groups from different kinetic standpoints. ${ }^{21-34}$ Among the standpoints, the presence of the hydroxo group of the central metal ion enhances the reactivity of macrocyclic porphyrins through the formation of hydrogen bonding between the oxygen atom of the hydroxo-ligand and the pyrrolic hydrogen atom of the free base porphyrin. ${ }^{23,27,34}$

Nickel is an essential element for humans as well as for other animals in functioning many metabolic reactions. The known multifunctional properties of the porphyrins and metalloporphyrins have been extended the porphyrins' research in various fields. So, the study of kinetics and mechanism of the formation of $\mathrm{Ni}(\mathrm{II})$ porphyrin may open a new research arena of applications of nickel-porphyrin complexes. Nickel is a transition metal having $d^{8}$ electronic configuration, thus exhibits the least reactivity in complex formation. However, in our previous study, we found enhanced reactivity of $\mathrm{Au}^{3+}$ ion in the formation of complexes with the macrocyclic tetrakis(N-methylpyridinium-4yl)porphyrin, $\left[\mathrm{H}_{2} \mathrm{TMPyP}\right]^{4+}$, where $\mathrm{Au}^{3+}$ ion belongs to the $d^{8}$ electronic configuration. ${ }^{27}$ According to the speciation diagram of $\mathrm{Au}^{3+}$ ion with solution $\mathrm{pH}$, the monohydroxotrichloroaurate(III), $\left[\mathrm{AuCl}_{3}(\mathrm{OH})\right]^{-}$, was found as a predominant species under the experimental condition. ${ }^{27}$ The negatively charged $\left[\mathrm{AuCl}_{3}(\mathrm{OH})\right]^{-}$ion can easily approach the core of the tetracationic porphyrin and the presence of the hydroxo-ligand in the $\mathrm{Au}^{3+}$ species causes enhanced reactivity in the formation of the $[\mathrm{Au}(\mathrm{III}) \mathrm{TMPyP}]^{5+}$ complex. This is because the hydroxo-ligand of the $\left[\mathrm{AuCl}_{3}(\mathrm{OH})\right]^{-}$species forms hydrogen bonding with the pyrrolic hydrogen atom of the porphyrin, which resulted in an enhanced rate of the reaction. Thus, it is suspected that the monohydroxonickel(II), $\left[\mathrm{Ni}\left(\mathrm{H}_{2} \mathrm{O}\right)_{5}(\mathrm{OH})\right]^{+}$, species may also exhibit enhance reactivity with the free-base porphyrin, $\left[\mathrm{H}_{2} \mathrm{TMPyP}\right]^{4+}$. In kinetic studies, the speciation of central metal ion plays a vital role to investigate the reactivity and mechanism of the reactions. Though some attempts have already been paid to study the kinetics of formation of $\mathrm{Ni}(\mathrm{II})$ porphyrins, ${ }^{35-38}$ speciation of $\mathrm{Ni}$ (II) ion from the geo- and hydrothermal points of view is available. ${ }^{39,40}$

Much attention has been paid to explore the interaction between the cationic porphyrins and nucleic acids because of the promising properties of the porphyrins in medical and biological applications. ${ }^{2,3,5-7,9-17,41-51}$ The potential uses of the porphyrins in medical and biological fields are due to their anticancer, ${ }^{11,13,17}$ antiviral and/or antibacterial/ anti-inflammatory ${ }^{4,6,10,14-16}$ and antifungal ${ }^{6,52}$ activities. Porphyrins are also being used as imaging agents in medical imaging systems. ${ }^{6,53-55}$ Cationic porphyrins interact with DNA in various modes. Three major modes of interaction between porphyrins and DNA are intercalation, outside binding without self-stacking, and outside binding with self-stacking along the DNA surface. ${ }^{41-46}$ Partial intercalation has also been suggested. ${ }^{45,46}$ It is noted that potential applications of porphyrins in medical and biological systems depend mainly on the modes of interaction of the porphyrinDNA adducts.

Very recently Liu and Li (2020) studied the severe health effect of the novel coronavirus (COVID-19) worldwide by applying theoretical models. ${ }^{56,57}$ They used conserved domain analysis, homology modeling and molecular docking models to compare the biological roles of specific proteins of the COVID-19, and found the novel coronavirus attacks the 1-beta chain of the haemoglobin and captures the protoporphyrin IX to inhibit human heme metabolism. The theoretical results suggest that the coronavirus has a strong affinity for porphyrins. The noble but clinically relevant finding encouraged us to investigate possible applications of the porphyrins as anti-COVID-19 agents.

In this paper, speciation of $\mathrm{Ni}^{2+}$ in an aqueous medium with different solution $\mathrm{pH}$ in $I=0.10 \mathrm{M}$ $\left(\mathrm{NaNO}_{3}\right)$ and $0.10 \mathrm{M} \mathrm{NaCl}$ at $25 \pm 1{ }^{\circ} \mathrm{C}$ has been characterized. By applying the distribution of the $\mathrm{Ni}^{2+}$

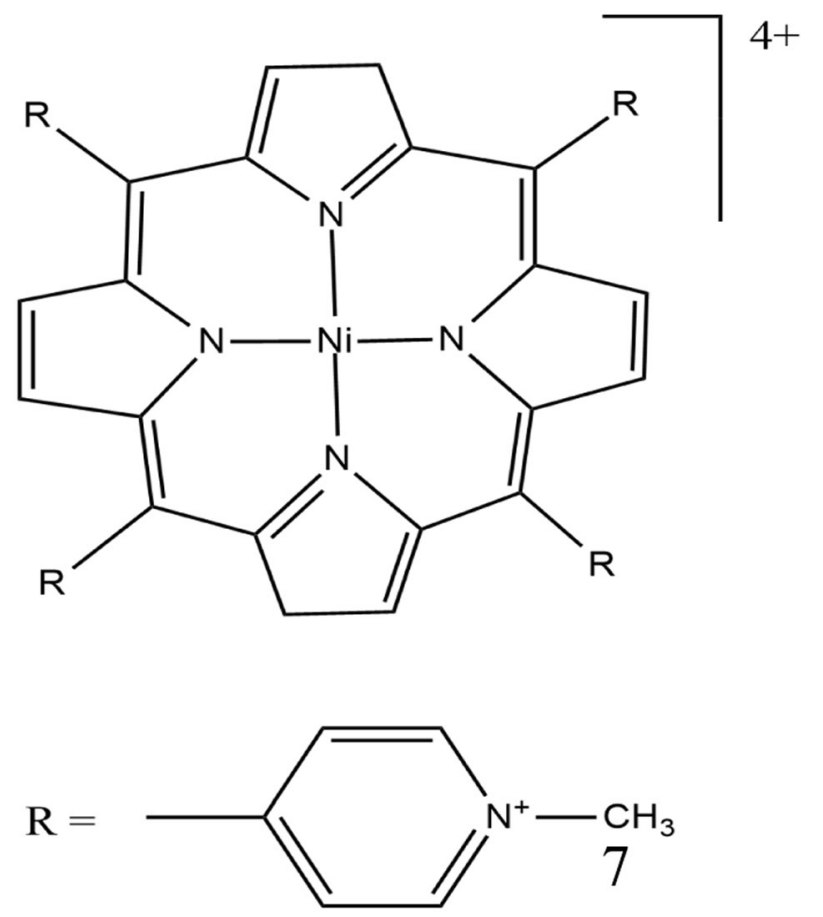

Scheme 1. Tetracationic nickel(II)porphyrin, I. 
species with solution $\mathrm{pH}$, the kinetics of the formation of $[\mathrm{Ni}(\mathrm{II}) \mathrm{TMPyP}]^{4+}$ complex, I (Scheme 1) has been studied to explore the reaction mechanism of the metalation reaction. We have extended our studies on the interaction of DNA with the $[\mathrm{Ni}(\mathrm{II}) \mathrm{TMPyP}]^{4+}$ complex along the $\mathrm{H}_{2} \mathrm{TMPyP}^{4+}$ to investigate their potential applications in medical and biological fields. An investigation of the application of porphyrins, particularly $\quad \mathrm{Ni}^{2+}, \quad, \quad \mathrm{Zn}^{2+}, \quad \mathrm{Ru}^{2+}, \quad \mathrm{Pt}^{2+}$, $[\mathrm{Au}(\mathrm{III}) \mathrm{TMPyP}]^{5+}$ as anti-COVID-19 agents is now in progress under an international research collaboration.

\section{Experimental}

\subsection{Reagents and materials}

The tetracationic free-base porphyrin, 5,10,15,20tetrakis(N-methylpyridinium-4-yl)porphyrin,

$\left[\mathrm{H}_{2}\right.$ TMPyP $]^{4+}$, was purchased as a tosylate from Dojindo Chemical Institute, Kumamoto, Japan. A $50 \mathrm{~mL}$ porphyrin solution was prepared by dissolving $68.18 \mathrm{mg}$ of the free base porphyrin, $\left[\mathrm{H}_{2} \mathrm{TMPyP}\right]^{4+}$, in distilled water. A standard $\mathrm{Cu}^{2+}$ solution was used to standardize the porphyrin solution by using spectrophotometric titration (molar ratio method). ${ }^{27,46,47}$ Nickel solution was prepared by dissolving the requisite amount of $\mathrm{NiCl}_{2} \cdot 6 \mathrm{H}_{2} \mathrm{O}$ (Merck, Germany) in an aqueous solution and the concentration was measured by using an atomic absorption spectrophotometer (Perkin Elmer, AAanalyst 200). Sodium nitrate, sodium hydroxide and hydrochloric acid were purchased from Merck, Germany. All the chemicals/ reagents were used without further purification. Tetracation nickel(II) porphyrin, [Ni(II)TMPyP $]^{4+}$, was prepared and absorption spectra were recorded in water at $\mathrm{pH} 9.50$ containing $0.10 \mathrm{M} \mathrm{NaNO}_{3}$. Absorption maximum $\left(\lambda_{\max }\right)$ and molar extinction coefficient $(\varepsilon)$ of the prepared $[\mathrm{Ni}(\mathrm{II}) \mathrm{TMPyP}]^{4+}$ complex were $436 \mathrm{~nm}$ and $114 \times 10^{3} \mathrm{M}^{-1} \mathrm{~cm}^{-1}$, respectively (Figure 1). ${ }^{58}$

A stock solution of salmon fish sperm DNA, purchased from Sigma-Aldrich, was prepared by dissolving in distilled water and the concentration in base pairs was determined by knowing the absorbance at $\lambda_{\max }=260 \mathrm{~nm}$ and using the molar extinction coefficient, $\varepsilon_{260}=1.32 \times 104 \mathrm{M}^{-1} \mathrm{~cm}^{-1}$. ${ }^{45,46}$ Stock solution of the DNA was kept in a refrigerator at $-4^{\circ} \mathrm{C}$. The frozen DNA solution was incubated in a water bath at $37{ }^{\circ} \mathrm{C}$ for an hour and diluted as required before the experiment. Acetate/sodium acetate and 2-[4-(2-hydroxyethyl)-1-piperazinyl] ethanesulfonic acid (HEPES, Sigma-Aldrich) buffer

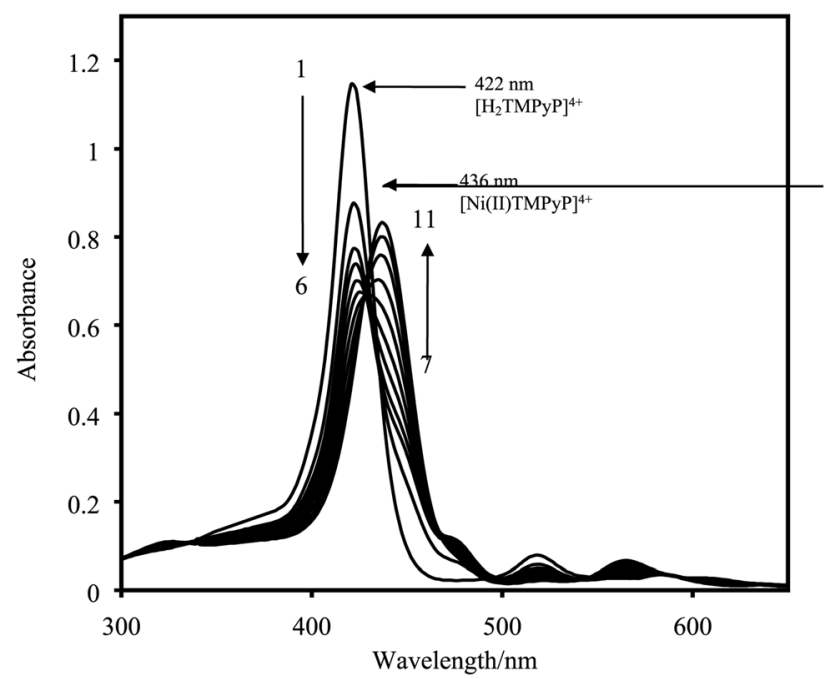

Figure 1. Absorption spectra of $[\mathrm{Ni}(\mathrm{II}) \mathrm{TMPyP}]^{4+}$ complex with time at solution $\mathrm{pH}=9.50\left(25^{\circ} \mathrm{C}\right)$ in $I=0.10 \mathrm{M}$ $\left(\mathrm{NaNO}_{3}\right) \cdot\left[\mathrm{Ni}^{2+}\right]=1.00 \times 10^{-3} \mathrm{M} ;\left[\mathrm{H}_{2} \mathrm{TMPyP}\right]^{4+}=1.24 \times$ $10^{-5} \mathrm{M}$. Progress of the formation of the $[\mathrm{Ni}(\mathrm{II}) \mathrm{TMPyP}]^{4+}$ complex was monitored by changing the absorbance of $\left[\mathrm{H}_{2} \mathrm{TMPyP}\right]^{4+}$ at $\lambda_{\max }=422 \mathrm{~nm}$ with time. The formation time are as follows: (1): 0 ; (2): 5 ; (3) 10; (4): 20; (5): 30; (6): 50; (7): 70; (8): 100; (9): 140; (10): 200; (11): $260 \mathrm{~min}$, respectively.

solution was prepared in $100 \mathrm{~mL}$ distilled water as stock solutions and used with required dilution throughout the experiments. $\mathrm{pH}$ of the HEPES solution $(0.10 \mathrm{M})$ was adjusted to 7.40 upon addition of either $\mathrm{NaOH}$ or $\mathrm{HCl}$. In this work, distilled water was used to perform all the experiments.

\subsection{Speciation of $\mathrm{Ni}(\mathrm{II})$ complexes}

Solutions of $5.00 \times 10^{-3} \mathrm{M} \mathrm{NiCl}_{2}$ with changing solution $\mathrm{pH}$ from 2.97 to 11.40 , were prepared in $50 \mathrm{~mL}$ volumetric flasks separately. The requisite volume of sodium nitrate was added to each solution in order to maintain ionic strength $(I=0.10 \mathrm{M})$. Solution $\mathrm{pH}$ was adjusted by the addition of either $\mathrm{HCl}$ or $\mathrm{NaOH}$ in acetate buffer ([Acetate] $=0.02 \mathrm{M}$ ). The UV-Vis spectra of the $\mathrm{Ni}^{2+}$ species were recorded by using a double beam UV-Vis spectrophotometer (SHIMADZU, Model UV-1800) within a range from 350 to $500 \mathrm{~nm}$. A number of $\mathrm{Ni}^{2+}$ solutions $\left(5.00 \times 10^{-3} \mathrm{M}\right)$ with different concentration of acetate ion ranging from 0 to $1.00 \times 10^{-2} \mathrm{M}$ was prepared under the same experimental conditions to investigate the interaction between $\mathrm{Ni}^{2+}$ and acetate ions and found no formation of $\mathrm{Ni}(\mathrm{II})-$ acetate complex. A pH meter (HANNA HI 2211) was used to measure the solution $\mathrm{pH}$. 


\subsection{Kinetics of formation of $[\mathrm{Ni}(\mathrm{II}) \mathrm{TMPyP}]^{4+}$ complex}

Pseudo-first order condition was kept constant throughout the experiment in order to explore the kinetics of the reactions between tetracationic freebase porphyrin and $\mathrm{Ni}^{2+}$ species in $I=0.10 \mathrm{M}$ $\left(\mathrm{NaNO}_{3}\right)$ at $25 \pm 1{ }^{\circ} \mathrm{C}$ where the $\mathrm{pH}$ of the solutions were varied from 2.97 to 11.05 . The concentration of $\mathrm{Ni}^{2+}$ was varied from $0.50 \times 10^{-3}$ to $5.00 \times 10^{-3} \mathrm{M}$ while that for the porphyrin, $\left[\mathrm{H}_{2} \mathrm{TMPyP}^{4+}\right.$, was kept constant at $1.24 \times 10^{-5} \mathrm{M}$. The metalloporphyrin was prepared by mixing the porphyrin solution with the $\mathrm{Ni}^{2+}$ solution in a $1-\mathrm{cm}$ cell compartment and preequilibrated at $25 \pm 1{ }^{\circ} \mathrm{C}$. The change in the absorbance was monitored as a function of time at $422 \mathrm{~nm}$ $\left(\lambda_{\max }\right.$ of $\left.\left[\mathrm{H}_{2} \mathrm{TMPyP}\right]^{4+}\right)$ by using a UV-Vis spectrophotometer (SHIMADZU, Model UV-1800). Formation of the $[\mathrm{Ni}(\mathrm{II}) \mathrm{TMPyP}]^{4+}$ complex was monitored by observing isosbestic points at 431, 490 and $546 \mathrm{~nm}$ in the visible region as the porphyrin reacted with the $\mathrm{Ni}^{2+}$ species. Appearing the isosbestic points is confirming the free-base porphyrin and $\mathrm{Ni}(\mathrm{II})$ porphyrin complex are only the absorbing species. Figure 1 shows such a spectral pattern of the formation of the $[\mathrm{Ni}(\mathrm{II}) \mathrm{TMPyP}]^{4+}$ complex with time. To obtain the observed rate constants $\left(k_{\text {obs }}\right)$, values of $\ln \left(A_{\mathrm{t}}-A_{\alpha}\right)$ were plotted with time and found linearity over two half-lives. Rate constants for the reactions between the free-base porphyrin and $\mathrm{Ni}^{2+}$ species were determined by varying solution $\mathrm{pH}$, nickel concentrations and ionic strengths. The duplicate runs under the same conditions agreed within a 5\% error. A pH meter (HANNA HI 2211) was used to measure the $\mathrm{pH}$ of the solution.

\subsection{Interaction of $[\mathrm{Ni}(\mathrm{II}) \mathrm{TMPyP}]^{4+}$ complex with DNA}

The UV-Vis spectra of the free base porphyrin and $[\mathrm{Ni}(\mathrm{II}) \mathrm{TMPyP}]^{4+}$ complex upon addition of DNA were recorded by using a double-beam UV-Vis spectrophotometer (UV-1800, Shimadzu, Japan). A fluorescence spectrophotometer (F-7000, Hitachi, Japan) was used to record the luminescence spectra for the free base porphyrin and the $\mathrm{Ni}(\mathrm{II})$ porphyrin in the presence of DNA. The fluorescence emission wavelength was scanned from 550 to $800 \mathrm{~nm}$ by setting the excitation wavelength at 446 and $431 \mathrm{~nm}$ for the $[\mathrm{Ni}(\mathrm{II}) \mathrm{TMPyP}]^{4+}$ and $\left[\mathrm{H}_{2} \mathrm{TMPyP}^{4+}\right.$, respectively. This is because the isosbestic points for the binary system of $[\mathrm{Ni}(\mathrm{II}) \mathrm{TMPyP}]^{4+}$-DNA and $\left[\mathrm{H}_{2} \mathrm{TMPyP}^{4+}{ }_{-}\right.$
DNA were observed at 446 and $431 \mathrm{~nm}$, respectively. Under the present experimental conditions, for $1.14 \times$ $10^{-5} \mathrm{M}$ of $[\mathrm{Ni}(\mathrm{II}) \mathrm{TMPyP}]^{4+}$ and $\left[\mathrm{H}_{2} \mathrm{TMPyP}^{4+}\right.$, the absorbance and luminescence spectra of the porphyrin solutions were not affected by the species adsorbed on the surface of the cell wall. These were confirmed by recording a UV-vis spectrum of ethanol-water after discarding the analyte solution and found no peaks from the ethanol-water. All the experiments were carried out under room light. HEPES solution of $0.02 \mathrm{M}$ ( $\mathrm{pH} 7.40$ ) was used throughout the experiment. A pH meter (HANNA HI 2211) was used to measure the solution $\mathrm{pH}$.

\section{Results and Discussion}

\subsection{Speciation of $\mathrm{Ni}^{2+}$}

Speciation of $\mathrm{Ni}^{2+}$ ion in aqueous solution in the presence of $0.10 \mathrm{M}$ of $\mathrm{NaNO}_{3}(I)$ at $25 \pm 1{ }^{\circ} \mathrm{C}$ was carried out to investigate the kinetics of the reaction between the free-base porphyrin, $\left[\mathrm{H}_{2} \mathrm{TMPyP}\right]^{4+}$, and the $\mathrm{Ni}^{2+}$ species. In order to investigate the kinetics of the metalation reaction, it is highly expected to know the speciation of the relevant metal ion. This is because the speciation diagram provides species distribution that is required to establish the reaction mechanism for the relevant reaction. Figure 2 shows the speciation diagram generated from the hydrolysis constants of $\mathrm{Ni}^{2+}$ species with the solution $\mathrm{pH} .{ }^{59} \mathrm{As}$

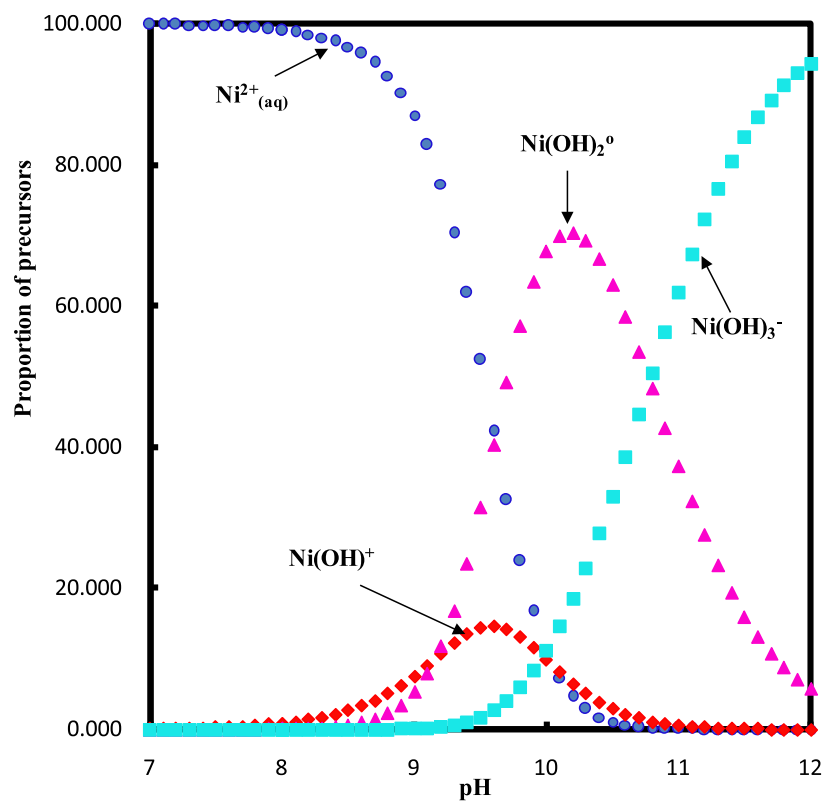

Figure 2. Speciation diagram of $\mathrm{Ni}^{2+}$ species as a function of solution $\mathrm{pH}$. The diagram is reproduced on the basis of hydrolysis constants of $\mathrm{Ni}^{2+} .59$ 
seen from Figure 2, the hexaaqua $\mathrm{Ni}^{2+},\left[\mathrm{Ni}\left(\mathrm{H}_{2} \mathrm{O}\right)_{6}\right]^{2+}$ simply written as $\mathrm{Ni}^{2+}{ }_{(\mathrm{aq})}$, species predominantly exists from the acidic to even alkaline $\mathrm{pH}(\sim 9.50)$ and is converting to hydroxo species, $\left[\mathrm{Ni}\left(\mathrm{H}_{2} \mathrm{O}\right)_{6-\mathrm{n}}(\mathrm{OH})_{\mathrm{n}}\right]^{2-\mathrm{n}}$, through successive replacement of the $\mathrm{H}_{2} \mathrm{O}$ molecule by the $\mathrm{OH}^{-}$groups with increasing the solution $\mathrm{pH}$. The aqua-monohydroxo $\mathrm{Ni}^{2+},\left[\mathrm{Ni}\left(\mathrm{H}_{2} \mathrm{O}\right)_{5}(\mathrm{OH})\right]^{+}$, species is distributed from $\mathrm{pH} \sim 7.90$ to 11.00 with the maximum distribution that observed at $\mathrm{pH} 9.50$ (Figure 2). Like $\mathrm{Ni}^{2+}{ }_{\text {(aq) }}$ ions, the monohydroxo $\mathrm{Ni}^{2+}$ ions, $\left[\mathrm{Ni}\left(\mathrm{H}_{2-}\right.\right.$ $\left.\mathrm{O})_{5}(\mathrm{OH})\right]^{+}$, are also aquatic species, thus they take part in metalation reaction with the water-soluble free-base porphyrin, $\left[\mathrm{H}_{2} \mathrm{TMPyP}\right]^{4+}$, significantly in the aqueous medium.

On the other hand, a small fraction of the dihydroxo $\mathrm{Ni}^{2+},\left[\mathrm{Ni}\left(\mathrm{H}_{2} \mathrm{O}\right)_{4}(\mathrm{OH})_{2}\right]^{0}$, species reacts with the free-base porphyrin, $\left[\mathrm{H}_{2} \mathrm{TMPyP}\right]^{4+}$, because of its very poor existence in the aqueous system under the present experimental conditions. The solubility product for the dihydroxo $\mathrm{Ni}^{2+}$ species is only $K_{\mathrm{S} 10}^{\mathrm{b}}=-$ 15.7 , thus it starts to precipitate at $\mathrm{pH} \sim 8.15$ for $10^{-3}$ $\mathrm{M}$ of $\mathrm{Ni}^{2+}$ solution. ${ }^{59}$ This causes the presence of a small fraction of the $\left[\mathrm{Ni}\left(\mathrm{H}_{2} \mathrm{O}\right)_{4}(\mathrm{OH})_{2}\right]^{0}$ species in this study (Figure 2). According to the speciation diagram, the $\left[\mathrm{Ni}\left(\mathrm{H}_{2} \mathrm{O}\right)_{4}(\mathrm{OH})_{2}\right]^{0}$ species is distributed from $\mathrm{pH} \sim 8.25$ to the higher $\mathrm{pH}(\geq 12.00)$ where its maximum distribution is observed at $\mathrm{pH} \sim 10.30$ (Figure 2). It is expected that the reactivity for the dihydroxo $\mathrm{Ni}^{2+}$, $\left[\mathrm{Ni}\left(\mathrm{H}_{2} \mathrm{O}\right)_{4}(\mathrm{OH})_{2}\right]^{0}$, species towards the free-base porphyrin, $\left[\mathrm{H}_{2} \mathrm{TMPyP}\right]^{4+}$, would be higher than that of the monohydroxo, $\left[\mathrm{Ni}\left(\mathrm{H}_{2} \mathrm{O}\right)_{5}(-\right.$ $\mathrm{OH})]^{+}$, species. This is because the dihydroxo species is electrically neutral, thus the $\left[\mathrm{Ni}\left(\mathrm{H}_{2} \mathrm{O}\right)_{4}(\mathrm{OH})_{2}\right]^{0}$ species can easily approach the tetracationic porphyrin's core without any Coulombic force of repulsion while the unipositive aqua monohydroxo $\mathrm{Ni}^{2+},\left[\mathrm{Ni}\left(\mathrm{H}_{2} \mathrm{O}\right)_{5}(\mathrm{OH})\right]^{+}$, species could suffer from the repulsive force. The dihydroxo $\mathrm{Ni}^{2+}$ species exists with a small fraction in the aqueous systems because of its very low solubility product, $K_{\text {S10 }}^{\mathrm{b}}=$ 15.7, under the present experimental conditions $\left(\left[\mathrm{Ni}^{2+}\right]=10^{-3} \mathrm{M} ; I=0.10 \mathrm{M}, \mathrm{NaNO}_{3}\right)$, therefore, it is reasonable to observe the less reactivity for the $\left[\mathrm{Ni}\left(\mathrm{H}_{2} \mathrm{O}\right)_{4}(\mathrm{OH})_{2}\right]^{0}$ species towards the $\left[\mathrm{H}_{2} \mathrm{TMPyP}\right]^{4+}$ as described in the kinetics section. The trihydroxo $\mathrm{Ni}^{2+},\left[\mathrm{Ni}\left(\mathrm{H}_{2} \mathrm{O}\right)_{3}(\mathrm{OH})_{3}\right]^{-}$species is distributed from $\mathrm{pH} 9.4$ to the higher $\mathrm{pH}>12.00$ while its distribution is so small $\sim 1-2 \%$ at the experimental solution $\mathrm{pH}$, 9.50 (Figure 2).

The UV-Vis spectral data also confirm the stepwise formation of the hydroxo $\mathrm{Ni}^{2+},\left[\mathrm{Ni}^{2}\left(\mathrm{H}_{2} \mathrm{O}\right)_{6-\mathrm{n}}(\mathrm{OH})_{\mathrm{n}}\right]^{2-\mathrm{n}}$, species as a function of the solution $\mathrm{pH}$ (Figure $\mathrm{S} 1$, Supplementary Information). As mentioned above, the
$\mathrm{Ni}^{2+}$ exists in an aqueous system as hexaaqua, $\left[\mathrm{Ni}\left(\mathrm{H}_{2} \mathrm{O}\right)_{6}\right]^{2+}$, species. The $\left[\mathrm{Ni}\left(\mathrm{H}_{2} \mathrm{O}\right)_{6}\right]^{2+}$ species shows the ligand to metal charge transfer (LMCT) transition and the absorption maximum is centered at $\lambda_{\text {max }}=391 \mathrm{~nm}$ in the UV region (Figure S1, Supplementary Information). The LMCT transitions have been assigned due to the charge transfer from bonding or nonbonding p-orbital of ligand to high energy antibonding $d \mathrm{p}^{*}$-orbital of the metal ion. ${ }^{60}$ The UVVis absorption spectra for $\mathrm{Ni}^{2+}\left(1.0 \times 10^{-3} \mathrm{M}\right)$ in $0.10 \mathrm{M} \mathrm{NaNO}_{3}$ solutions with different solution $\mathrm{pH}$ are shown in Figure S1, Supplementary Information. As seen from Figure S1, Supplementary Information, the intensity of the peak centered at $\lambda_{\max } 391 \mathrm{~nm}$ that gradually decreases as a function of solution $\mathrm{pH}$ and reaches at a flat with the higher $\mathrm{pH}$ value, $\sim 10.30$. This result suggests that the hexaaqua $\mathrm{Ni}^{2+},\left[\mathrm{Ni}\left(\mathrm{H}_{2-}\right.\right.$ $\left.\mathrm{O})_{6}\right]^{2+}$, species are converting to hydroxo, $\left[\mathrm{Ni}\left(\mathrm{H}_{2} \mathrm{O}\right)_{6-}\right.$ $\left.{ }_{n}(\mathrm{OH})_{n}\right]^{2-n}$, species through stepwise replacement of the $\mathrm{H}_{2} \mathrm{O}$ by the $\mathrm{OH}^{-}$with increasing the solution $\mathrm{pH}$ from 2.97 to 11.40 . It is noted that the solution does not show any clear absorption maxima between 350 and $450 \mathrm{~nm}$ at $\mathrm{pH} \geq 10.30$. This is because of the formation of the dihydroxo $\mathrm{Ni}^{2+},\left[\mathrm{Ni}\left(\mathrm{H}_{2} \mathrm{O}\right)_{4}(\mathrm{OH})_{2}\right]^{0}$, species and then phases out from the aqueous solution as $\mathrm{Ni}(\mathrm{OH})_{2}{ }^{0}\left(K_{\mathrm{S} 10}^{\mathrm{b}}=-15.7\right)$, thereby resulting in presence of an insignificant amount of the UV-active species in the aqueous system (Figure S1, Supplementary Information). ${ }^{59}$ Therefore, it may conclude that the hexaaqua $\mathrm{Ni}^{2+},\left[\mathrm{Ni}\left(\mathrm{H}_{2} \mathrm{O}\right)_{6}\right]^{2+}$, species co-exists with the $\left[\mathrm{Ni}\left(\mathrm{H}_{2} \mathrm{O}\right)_{6-\mathrm{n}}(\mathrm{OH})_{\mathrm{n}}\right]^{2-\mathrm{n}}[\mathrm{n}=1, \ldots, 6]$ within a $\mathrm{pH}$ range from $\sim 2$ to 14 according to the following equations: ${ }^{59}$

$$
\begin{aligned}
& \mathrm{Ni}_{(\mathrm{aq})}^{2+}+\mathrm{OH}^{-} \stackrel{+\mathrm{OH}^{-}}{\rightleftharpoons} \mathrm{Ni}(\mathrm{OH})_{(\mathrm{aq})}^{+} \\
& \mathrm{Ni}(\mathrm{OH})^{+}{ }_{(\mathrm{aq})}+\mathrm{OH}^{-} \stackrel{+\mathrm{OH}^{-}}{\rightleftharpoons} \mathrm{Ni}(\mathrm{OH})^{+}{ }_{2(\mathrm{aq})} \\
& \mathrm{Ni}(\mathrm{OH})^{+}{ }_{2(\mathrm{aq})}+\mathrm{OH}^{-} \stackrel{+\mathrm{OH}^{-}}{\rightleftharpoons} \mathrm{Ni}(\mathrm{OH})^{-} \\
& \mathrm{Ni}(\mathrm{OH})^{-}{ }_{3}+\mathrm{OH}^{-} \stackrel{+\mathrm{OH}^{-}}{\rightleftharpoons} \mathrm{Ni}(\mathrm{OH})^{2-}{ }_{4}
\end{aligned}
$$

\subsection{Kinetics of formation of $[\mathrm{Ni}(\mathrm{II}) \mathrm{TMPyP}]^{4+}$ complex}

Changing the absorbance of the free base porphyrin, $\left[\mathrm{H}_{2} \mathrm{TMPyP}\right]^{4+}$, at $\lambda_{\max }=422 \mathrm{~nm}$ with time is a signature to monitor the progress of formation of the $[\mathrm{Ni}(\mathrm{II}) \mathrm{TMPyP}]^{4+}$ complex. Thus, this event has been taken into account to investigate the kinetics of $\mathrm{Ni}^{2+}$ 
into the free base porphyrin, $\left[\mathrm{H}_{2} \mathrm{TMPyP}\right]^{4+}$, in an aqueous medium at $25 \pm 1{ }^{\circ} \mathrm{C}$ in $I=0.10 \mathrm{M}\left(\mathrm{NaNO}_{3}\right)$. The spectral pattern of the formation of the $[\mathrm{Ni}(\mathrm{II}) \mathrm{TMPyP}]^{4+}$ complex is shown in Figure 1. The variation of the absorbance depicted as $\ln \left(A_{\mathrm{t}}-A_{\alpha}\right)$ was plotted with time in order to achieve the observed rate constants for the reactions between the $\left[\mathrm{H}_{2} \mathrm{TMPyP}\right]^{4+}$ and $\left[\mathrm{Ni}\left(\mathrm{H}_{2} \mathrm{O}\right)_{6-n}(\mathrm{OH})_{n}\right]^{2-n}$ species as a function of solution $\mathrm{pH}$.

The rate of formation of the $[\mathrm{Ni}(\mathrm{II}) \mathrm{TMPyP}]^{4+}$ complex is first order with respect to the free base porphyrin that can be written by the following equation:

$$
\begin{aligned}
-\mathrm{d}\left[\mathrm{H}_{2} \mathrm{TMPyP}^{4+}\right] / \mathrm{dt} & =k_{\mathrm{obs}}\left[\mathrm{H}_{2} \mathrm{TMPyP}^{4+}\right] \\
& =k_{\mathrm{f}}\left[\mathrm{Ni}^{2+}\right]\left[\mathrm{H}_{2} \mathrm{TMPyP}^{4+}\right]
\end{aligned}
$$

where $k_{\mathrm{obs}}$ is the observed first-order rate constant and $k_{\mathrm{f}}$ is the second order formation rate constant.

From the reactions between the $\left[\mathrm{H}_{2} \mathrm{TMPyP}\right]^{4+}$ and $\mathrm{Ni}^{2+}$ species at different solution $\mathrm{pH}$, the observed rate constants $\left(k_{\mathrm{obs}}\right)$ were measured to explore the reactivity of the various $\left[\mathrm{Ni}\left(\mathrm{H}_{2} \mathrm{O}\right)_{6-n}(\mathrm{OH})_{n}\right]^{2-n}$ species. The values of the observed rate constants for the reactions of the free base porphyrins with the $\mathrm{Ni}^{2+}$ species as a function of solution $\mathrm{pH}$ are shown in Figure 3. As seen from Figure 3, the observed rate constant increases as a function of the solution $\mathrm{pH}$ and goes to its maximum value at $\mathrm{pH} 9.50$ and then slows down as $\mathrm{pH}$ is being increased. The rising trend for the rate constants almost remains constant

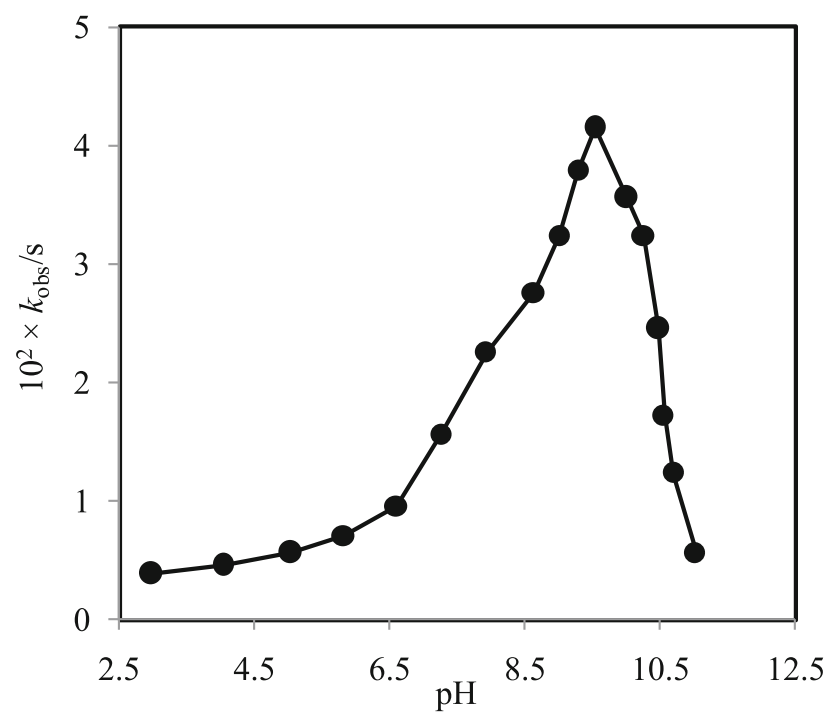

Figure 3. Observed rate constants $\left(k_{\mathrm{obs}}\right)$ with solution $\mathrm{pH}$ within a range from 2.97 to 11.02 in $I=0.10 \mathrm{M}\left(\mathrm{NaNO}_{3}\right)$ at $25 \pm 1{ }^{\circ} \mathrm{C} .\left[\mathrm{Ni}^{2+}\right]=1.00 \times 10^{-3} \mathrm{M} ;\left[\mathrm{H}_{2} \mathrm{TMPyP}^{4+}\right]=1.24 \times$ $10^{-5} \mathrm{M}$. until $\mathrm{pH} 6.60$ and then increases sharply with $\mathrm{pH}$. These results suggest that the reacting species of the $\mathrm{Ni}^{2+}$ ion is mostly hexaaqua $\mathrm{Ni}^{2+}$ ion, $\left[\mathrm{Ni}^{2}\left(\mathrm{H}_{2} \mathrm{O}\right)_{6}\right]^{2+}$ written as $\mathrm{Ni}^{2+}{ }_{(\mathrm{aq})}$, within the $\mathrm{pH}$ range from 2.97 to $\sim 8.00$ which is one of the less reactive among the $\left[\mathrm{Ni}\left(\mathrm{H}_{2} \mathrm{O}\right)_{6-\mathrm{n}}(\mathrm{OH})_{\mathrm{n}}\right]^{2-\mathrm{n}} \quad[\mathrm{n}=1, \quad \ldots, 6]$ species (Figure 2).

Thus, at low $\mathrm{pH}(3.00-6.60)$ and $0.10 \mathrm{M} \mathrm{NaNO}_{3}$, the main $\mathrm{Ni}^{2+}$ species is hexaaqua, $\left[\mathrm{Ni}\left(\mathrm{H}_{2} \mathrm{O}\right)_{6}\right]^{2+}$, and changes to monohydroxo $\left[\mathrm{Ni}\left(\mathrm{H}_{2} \mathrm{O}\right)_{5}(\mathrm{OH})^{+}\right]$, dihydroxo $\left[\mathrm{Ni}\left(\mathrm{H}_{2} \mathrm{O}\right)_{2}(\mathrm{OH})_{2}{ }^{0}\right]$, trihydroxo $\left[\mathrm{Ni}\left(\mathrm{H}_{2} \mathrm{O}\right)_{3}\right.$ $\left.(\mathrm{OH})_{3}{ }^{-}\right]$and tetrahydroxo $\left[\mathrm{Ni}\left(\mathrm{H}_{2} \mathrm{O}\right)_{2}(\mathrm{OH})_{4}{ }^{2-}\right]$ species as a function of solution $\mathrm{pH}$ that stated in equations 1 4. In our previous study, it has also been reported that $\mathrm{Zn}^{2+}$ ion exists predominantly as a hexaaqua, $\left[\mathrm{Zn}\left(\mathrm{H}_{2} \mathrm{O}\right)_{6}\right]^{2+}$, species at low $\mathrm{pH}(\sim 2-5)$ in $0.10 \mathrm{M}$ $\mathrm{NaNO}_{3}$, and changes to hydroxo species stepwise and finally converts to tetrahydroxo $\left[\mathrm{Zn}(\mathrm{OH})_{4}{ }^{-}\right]$species at higher solution $\mathrm{pH}^{34}$

As mentioned above, $\mathrm{Ni}^{2+}$ ion predominantly exists as hexaaquanickel(II), $\left[\mathrm{Ni}\left(\mathrm{H}_{2} \mathrm{O}\right)_{6}\right]^{2+}$, species at solution $\mathrm{pH}$ 3.0-8.0 and showed less reactivity in incorporation into the free base porphyrin, $\mathrm{H}_{2} \mathrm{TMPyP}^{4+}$. As the distribution of aqua-monohydroxo, $\left[\mathrm{Ni}\left(\mathrm{H}_{2} \mathrm{O}\right)_{5}\right.$ $(\mathrm{OH})]^{+}$, species increases, the reactivity of the $\mathrm{Ni}^{2+}$ ion also increases. As shown in Figure 3, the maximum observed rate constant is found at $\mathrm{pH}$ 9.50. This result is confirming the maximum distribution of the $\left[\mathrm{Ni}\left(\mathrm{H}_{2} \mathrm{O}\right)_{5}(\mathrm{OH})\right]^{+}$species at $\mathrm{pH} \sim 9.50$ and thus exhibited the highest reactivity towards the free-base porphyrin, $\left[\mathrm{H}_{2} \mathrm{TMPyP}\right]^{4+}$. With increasing the solution $\mathrm{pH}$, the distribution of the aqua-dihydroxo species of $\mathrm{Ni}^{2+},\left[\mathrm{Ni}\left(\mathrm{H}_{2} \mathrm{O}\right)_{4}(\mathrm{OH})_{2}\right]^{0}$, is being increased. With further increase the solution $\mathrm{pH}$, the presence of aquatrihydroxonickelate( $(\mathrm{II}),\left[\mathrm{Ni}\left(\mathrm{H}_{2} \mathrm{O}\right)_{3}(\mathrm{OH})_{3}\right]^{-}$, species is also increased and thus $\mathrm{Ni}^{2+}$ becomes less reactive towards the free-base porphyrin, $\left[\mathrm{H}_{2} \mathrm{TMPyP}\right]^{4+}$. Aqua-tetrahydroxonickelate(II), $\quad\left[\mathrm{Ni}_{(}\left(\mathrm{H}_{2} \mathrm{O}\right)_{2}(\mathrm{OH})_{4}\right]^{2-}$, species will be eventually the predominant species at the higher solution $\mathrm{pH}(\sim 12.00)$.

Therefore, the rate of incorporation of $\mathrm{Ni}^{2+}$ species into the $\left[\mathrm{H}_{2} \mathrm{TMPyP}\right]^{4+}$ (written $\mathrm{H}_{2} \mathrm{P}^{4+}$ is the simplest form of the $\left[\mathrm{H}_{2} \mathrm{TMPyP}\right]^{4+}$ ) is expressed by the following equations:

$$
\begin{aligned}
& \mathrm{Ni}^{2+}{ }_{(\mathrm{aq})}+\mathrm{H}_{2} \mathrm{P}^{4+} \stackrel{+\mathrm{OH}^{-}}{\rightleftharpoons} \mathrm{NiP}^{4+}+2 \mathrm{H}^{+} \\
& \mathrm{Ni}(\mathrm{OH})^{+}{ }_{(\mathrm{aq})}+\mathrm{H}_{2} \mathrm{P}^{4+} \stackrel{+\mathrm{OH}^{-}}{\rightleftharpoons} \mathrm{NiP}^{4+}+\mathrm{H}_{2} \mathrm{O}+\mathrm{H}^{+} \\
& \mathrm{Ni}(\mathrm{OH})_{2(\mathrm{aq})}+\mathrm{H}_{2} \mathrm{P}^{4+} \stackrel{+\mathrm{OH}^{-}}{\rightleftharpoons} \mathrm{NiP}^{4+}+2 \mathrm{H}_{2} \mathrm{O}
\end{aligned}
$$




$$
\mathrm{Ni}(\mathrm{OH})^{-}{ }_{3(\mathrm{aq})}+\mathrm{H}_{2} \mathrm{P}^{4+} \stackrel{\mathrm{OH}^{-}}{\rightleftharpoons} \mathrm{NiP}^{4+}+2 \mathrm{H}_{2} \mathrm{O}+\mathrm{OH}^{+}
$$

$$
\mathrm{Ni}(\mathrm{OH})_{4}^{2-}{ }_{(\mathrm{aq})}+\mathrm{H}_{2} \mathrm{P}^{4+} \stackrel{+\mathrm{OH}^{-}}{\rightleftharpoons} \mathrm{NiP}^{4+}+2 \mathrm{H}_{2} \mathrm{O}+2 \mathrm{OH}^{+}
$$

Since the reactivity of the aqua-tetrahydroxonickelate(II), $\left[\mathrm{Ni}\left(\mathrm{H}_{2} \mathrm{O}\right)_{2}(\mathrm{OH})_{4}\right]^{2-}$, species towards the $\left[\mathrm{H}_{2-}\right.$ $\mathrm{TMPyP}^{4+}$ is very poor and its negligible presence at pH 9.50, thus, eqs. (10) can be ignored. Therefore, eqs. (6) to (9) are taken into account in order to calculate the observed rate constants, $k_{\text {obs }}$.

$$
\text { Therefore, } \begin{aligned}
k_{\mathrm{obs}}= & k_{1}\left[\mathrm{Ni}_{(\mathrm{aq})}^{2+}\right]+k_{2}\left[\mathrm{Ni}(\mathrm{OH})_{(\mathrm{aq})}^{+}\right] \\
& +k_{3}\left[\mathrm{Ni}(\mathrm{OH})_{2}^{0}(\mathrm{aq})\right] \\
& +k_{4}\left[\mathrm{Ni}(\mathrm{OH})_{3}^{-}(\mathrm{aq})\right]
\end{aligned}
$$

As described above, the speciation diagram exhibited the distribution of the $\mathrm{Ni}^{2+}$ species, $\left[\mathrm{Ni}\left(\mathrm{H}_{2} \mathrm{O}\right)_{6-}\right.$ $\left.\mathrm{n}(\mathrm{OH})_{\mathrm{n}}\right]^{2-\mathrm{n}}$, with solution $\mathrm{pH}$, accordingly, their kinetics were also different. According to equ (11), the rate constants such as $k_{1}, k_{2}, k_{3}$ and $k_{4}$ belong to hexaaquanickel(II), dihydroxonickel(II), trihydroxonickelate(II) and tetrahydroxonickelate(II) species, respectively. Thus, the individual rate constant was calculated by taking as a mean of the observed rate constants. The calculated observed rate constants are as follows: $k_{1}=(0.62 \pm 0.22) \times 10^{-2} ; k_{2}=(3.60 \pm$ $0.40) \times 10^{-2} ; k_{3}=(2.09 \pm 0.52) \times 10^{-2}, k_{4}=(0.53 \pm$ $0.04) \times 10^{-2} \mathrm{M}^{-1} \mathrm{~s}^{-1}$ at $25 \pm 1{ }^{\circ} \mathrm{C}$ in $I=0.10 \mathrm{M}$ $\left(\mathrm{NaNO}_{3}\right)$ where $k_{2}>k_{3}>k_{1}>k_{4}$. From this sequence, it is concluded that the aqua-monohydroxo $\mathrm{Ni}^{2+}$, $\left[\mathrm{Ni}\left(\mathrm{H}_{2} \mathrm{O}\right)_{5}(\mathrm{OH})\right]^{+}$, species exhibited the highest reactivity among the $\mathrm{Ni}^{2+}$ species in reacting with the $\left[\mathrm{H}_{2} \text { TMPyP }\right]^{4+}$ where $k_{2}=3.60 \pm 0.40 \times 10^{-2} \mathrm{M}^{-1} \mathrm{~s}^{-1}$. It has been reported that monohydroxozinc(II), $[\mathrm{ZnOH}]^{+}$, species exhibited the enhanced reactivity with non- $N$-substituted porphyrins where $k_{\mathrm{ZnOH}}{ }^{+}>$ $k_{\mathrm{Zn} 2+(\mathrm{ag})}$, which is comparable to that found in this study. ${ }^{21,60-62}$ The enhanced rate constant has been ascribed to the formation of hydrogen bonding between the active oxygen atom of the hydroxo ligands and the pyrrolic hydrogen atom of the $\left[\mathrm{H}_{2-}\right.$ $\mathrm{TMPyP}^{4+}$. The $[\mathrm{ZnOH}]^{+}$species also exhibited enhanced reactivity towards $\mathrm{N}$-p-nitrobenzyl5,10,15,20-tetrakis(4-sulfonatophenyl)porphyrin. ${ }^{31}$ It is noted that the formation of hydrogen bonding between the oxygen atom of the $[\mathrm{ZnOH}]^{+}$species and the pyrrolic hydrogen atom of the free base porphyrin is responsible for the enhanced reactivity. In the incorporation of $\mathrm{Zn}^{2+}$ ion into the $\left[\mathrm{H}_{2} \mathrm{TMPyP}\right]^{4+}$, the presence of hydroxo ligands of the $\mathrm{Zn}^{2+}$ species enhances the reactivity that obeys the following sequence: $\quad k_{\mathrm{Zn}(\mathrm{H} 2 \mathrm{O}) 4(\mathrm{OH}) 2^{0}}>k_{\mathrm{Zn}(\mathrm{H} 2 \mathrm{O}) 3(\mathrm{OH})^{-}}>$ $k_{\mathrm{Zn}(\mathrm{H} 2 \mathrm{O}) 5(\mathrm{OH})}{ }^{+}>k_{\mathrm{Zn}(\mathrm{H} 2 \mathrm{O}) 6}{ }^{2+} \cdot{ }^{34}$ The monohydroxotrichloroaurate(III) species, $\left[\mathrm{AuCl}_{3}(\mathrm{OH})\right]^{-}, \quad$ also showed enhanced reactivity towards the $\left[\mathrm{H}_{2-}\right.$ $\mathrm{TMPyP}^{4+}$ where $k_{\mathrm{AuCl} 3(\mathrm{OH})}{ }^{-}>k_{\mathrm{AuCl} 4}{ }^{-}>k_{\mathrm{AuCl} 2(\mathrm{OH}) 2}{ }^{-}$ $>k_{\mathrm{AuCl}(\mathrm{OH}) 3}{ }^{-27}$ Schneider $(1975)$ reported that monohydroxocopper(II), $[\mathrm{Cu}(\mathrm{OH})]^{+}$, species exhibited much more reactivity towards the same free base porphyrin, $\left[\mathrm{H}_{2} \mathrm{TMPyP}\right]^{4+}$, compared to that of aquacopper(II), $\mathrm{Cu}^{2+}{ }_{(\mathrm{aq})}$, species, i.e., $k_{\mathrm{Cu}(\mathrm{OH})}{ }^{+}>>$ $k_{\mathrm{Cu} 2}{ }^{+63}$ The oxygen atom of the $[\mathrm{Cu}(\mathrm{OH})]^{+}$species forms $\mathrm{H}$-bonding with the pyrrolic hydrogen atom of the porphyrin core. This is the reason for its substantial reactivity with the free base porphyrin. It is, therefore, concluded that the presence of the $\mathrm{OH}^{-}$group of the aqua-monohydroxo, $\left[\mathrm{Ni}\left(\mathrm{H}_{2} \mathrm{O}\right)_{5}(\mathrm{OH})\right]^{+}$, species make possible for the formation of hydrogen bonding with the pyrrolic hydrogen atom, thus the $\mathrm{Ni}^{2+}$ species can easily approach to the porphyrin's core. The formation of the hydrogen bonding and fast displacement of $\mathrm{H}_{2} \mathrm{O}$ ligands from the $\mathrm{Ni}^{2+}$ species enhance the reactivity of the aqua-monohydroxo, $\left[\mathrm{Ni}\left(\mathrm{H}_{2} \mathrm{O}\right)_{5}(\mathrm{OH})\right]^{+}$, species. However, the aqua $\mathrm{Ni}^{2+},\left[\mathrm{Ni}\left(\mathrm{H}_{2} \mathrm{O}\right)_{6}\right]^{2+}$, species lack the hydroxo $\left(\mathrm{OH}^{-}\right)$ligands, thus it might have less approaching ability to the porphyrin's core. This is the reason for less reactivity of the $\mathrm{Ni}^{2+}$ (aq) species towards the $\left[\mathrm{H}_{2} \mathrm{TMPyP}\right]^{4+}\left(k_{1}=0.62 \pm 0.22 \times 10^{-2}\right.$ $\left.\mathrm{M}^{-1} \mathrm{~s}^{-1}\right)$. The hexaaqua $\mathrm{Ni}^{2+}$ ion, $\left[\mathrm{Ni}\left(\mathrm{H}_{2} \mathrm{O}\right)_{6}\right]^{2+}$, carries double positive charge that also decreases the reactivity of this species towards the tetracationic porphyrin, $\left[\mathrm{H}_{2} \mathrm{TMPyP}\right]^{4+}$. This is because of the development of Coulombic force of repulsion between the two positively charged species. It was expected to observe the highest reactivity for the aqua-dihydroxo, $\left[\mathrm{Ni}\left(\mathrm{H}_{2} \mathrm{O}\right)_{4}(\mathrm{OH})_{2}\right]^{0}$, towards the $\left[\mathrm{H}_{2} \mathrm{TMPyP}\right]^{4+}$, however, $\mathrm{Ni}(\mathrm{OH})_{2}{ }^{0}$ begins to precipitate at $\mathrm{pH} \sim 8.20$ for $10^{-3} \mathrm{M}$ of $\mathrm{Ni}^{2+}$ solution using the $\log K_{\mathrm{S} 10}^{\mathrm{b}}$ of -15.7 for the active $\mathrm{Ni}(\mathrm{OH})_{2}$ [Baes and Mesmer, 1976]. In contrast, the aqua-dihydroxo species of $\mathrm{Zn}^{2+}$, $\left[\mathrm{Zn}\left(\mathrm{H}_{2} \mathrm{O}\right)_{4}(\mathrm{OH})_{2}\right]^{0}$, showed the highest reactivity among the $\left[\mathrm{Zn}\left(\mathrm{H}_{2} \mathrm{O}\right)_{6-\mathrm{n}}(\mathrm{OH})_{n}\right]^{\mathrm{n}-2}$ species towards the free base porphyrin, $\left[\mathrm{H}_{2} \mathrm{TMPyP}\right]{ }^{4+} \cdot{ }^{34}$ Batinić-Haberle et al. (1999) used Marcus plot in order to determine the self-exchange rate constants for monohydroxoiron(III) porphyrins and aquamanganese(III) porphyrins, and they found that to be approximately 1 order of magnitude higher for the monohydroxoiron(III) porphyrins than those of aquamanganese(III) porphyrins. 4 
However, the hydroxospecies having a higher number of $\mathrm{OH}^{-}$groups showed less reactivity towards the $\left[\mathrm{H}_{2} \mathrm{TMPyP}\right]^{4+}$ and the reactivity of the $\left[\mathrm{Ni}\left(\mathrm{H}_{2} \mathrm{O}\right)_{6-}\right.$ $\left.{ }_{n}(\mathrm{OH})_{n}\right]^{2-n}$ species follows the decreasing sequence: $k_{\mathrm{Ni}(\mathrm{H} 2 \mathrm{O}) 5(\mathrm{OH})}^{+}>k_{\mathrm{Ni}(\mathrm{H} 2 \mathrm{O}) 4(\mathrm{OH}) 2}{ }^{0}>k_{\mathrm{Ni}(\mathrm{H} 2 \mathrm{O}) 3(\mathrm{OH}) 3}$ (Figure 3). Habib et al. (2004) reported that $\mathrm{AuCl}_{3}$ $(\mathrm{OH})^{-}$exhibited the highest reactivity towards the freebase porphyrin, $\left[\mathrm{H}_{2} \mathrm{TMPyP}\right]^{4+}$, among the $\left[\mathrm{AuCl}_{4-\mathrm{n}}\right.$ $\left.(\mathrm{OH})_{\mathrm{n}}\right]^{-}(\mathrm{n}=0,-, 4)$ species according to the following sequence: $k_{\mathrm{AuCl} 3(\mathrm{OH})}{ }^{-}>k_{\mathrm{AuCl} 2(\mathrm{OH}) 2}{ }^{-}>k_{\mathrm{AuCl}(\mathrm{OH}) 3}{ }^{-27}$ Paquette and Zador (1978) also reported that the reactivity of $\mathrm{Zn}^{2+}$ ion towards hematoporphyrin IX decreases with an increasing number of the $\mathrm{OH}^{-}$group coordinated to the $\mathrm{Zn}^{2+}$ ion and the reactivity order follows the sequence: $k_{\mathrm{Zn}(\mathrm{OH}) 2^{-}}>k_{\mathrm{Zn}(\mathrm{OH}) 3^{-}}>$ $k_{\mathrm{Zn}(\mathrm{OH}) 4}{ }^{-60}$ Cabbiness and Margerum (1969) reported that trihydroxocuprate(II), $\left[\mathrm{Cu}(\mathrm{OH})_{3}\right]^{-}$, species shows higher reactivity towards the hematoporphyrin IX than the tetrahydroxocuprate(II), $\left[\mathrm{Cu}(\mathrm{OH})_{4}\right]^{2-}$, i.e., $k_{\mathrm{Cu}(\mathrm{OH}) 3}$ $>k_{\mathrm{Cu}(\mathrm{OH}) 4}{ }^{2-} \cdot{ }^{32}$

It is noteworthy to mention that the $\mathrm{OH}^{-}$group coordinated to the metal ion plays a crucial role in enhancing the reactivity of the metal species towards the $\left[\mathrm{H}_{2} \mathrm{TMPyP}\right]^{4+}$. This is because the oxygen atom of the aqua-monohydroxo, $\left[\mathrm{Ni}\left(\mathrm{H}_{2} \mathrm{O}\right)_{5}(\mathrm{OH})\right]^{+}$, species forms hydrogen bonding with the pyrrolic hydrogen atom of the free base porphyrin, thus the aquamonohydroxo species can easily approach the porphyrin's core. The easy approach of the aqua-monohydroxonickel(II) species enhances its reactivity. On the other hand, the aqua $\mathrm{Ni}^{2+},\left[\mathrm{Ni}\left(\mathrm{H}_{2} \mathrm{O}\right)_{6}\right]^{2+}$, species lacks hydroxo ligand, so the aqua-species is incapable to form hydrogen bonding with the pyrrolic hydrogen atom. This is the reason for its less and/or least reactivity towards the $\left[\mathrm{H}_{2} \mathrm{TMPyP}\right]^{4+}$. However, the aquadihydroxo, $\left[\mathrm{Ni}\left(\mathrm{H}_{2} \mathrm{O}\right)_{4}(\mathrm{OH})_{2}\right]^{0}$, species exhibited less reactivity with the free-base porphyrin, $\left[\mathrm{H}_{2} \mathrm{TMPyP}\right]^{4+}$. This is because the aqua-dihydroxonickel(II) species take part in hydrolysis reaction at solution $\mathrm{pH} 8.20$ and then phases out from the aqueous system through precipitation reaction at higher $\mathrm{pH}$, e.g., 9.50. The precipitation reaction causes lesser distribution of the dihydroxonickel(II) species compared to the aquamonohydroxonickel(II) species at solution $\mathrm{pH} 9.50$ (Figure 2). The anionic trihydroxonickelate(II), $\left[\mathrm{Ni}\left(\mathrm{H}_{2} \mathrm{O}\right)_{3}(\mathrm{OH})_{3}\right]^{-}$, species seems to be exhibited better reactivity towards the cationic porphyrin $\left(\left[\mathrm{H}_{2-}\right.\right.$ $\mathrm{TMPyP}^{4+}$ ), however, the presence of the higher number of the hydroxo groups slows down its kinetics. $^{27,32,34,60}$ These results suggest that though the first $\mathrm{OH}^{-}$ligand is responsible for the formation of hydrogen bonding with the pyrrolic hydrogen atom, however, displacement of the remaining $\mathrm{OH}^{-}$seems slow.
It has been reported that the $\mathrm{OH}^{-}$group is strongly coordinated to the metal ion having $d^{8}$ electronic configuration like $\mathrm{Pt}^{2+}$ ion. ${ }^{64}$ The electronic configuration of $\mathrm{Ni}^{2+}$ is also $d^{8}$, so their chemical properties are supposed to be similar; hence the $\mathrm{OH}^{-}$groups are also strongly coordinated with the $\mathrm{Ni}^{2+}$ ion. Bailey and Hambright (2003) reported that $\mathrm{Cu}^{2+}$ ion exhibited the highest reactivity among the other first transition metal ions, such as $\mathrm{Zn}^{2+}, \mathrm{Co}^{2+}$ and $\mathrm{Ni}^{2+}$ towards the free base $\mathrm{H}_{2}-\mathrm{BrP}(4)^{4+}$ and tricationic $\mathrm{H}-\mathrm{BrP}(4)^{3+}$ porphyrins at $25{ }^{\circ} \mathrm{C}$ in $I=0.10 \mathrm{M}$ $\left(\mathrm{NaNO}_{3}\right)$ and the reactivity order was found to be $\mathrm{Cu}^{2+}$ $>\mathrm{Zn}^{2+}>\mathrm{Co}^{2+}>\mathrm{Ni}^{2+} \cdot{ }^{65}$ It is expected that the reactivity of $\mathrm{Ni}^{2+}$ among the divalent metal ions towards the porphyrins would be less because of its $d^{8}$ electronic configuration. However, the presence of hydroxo-ligands with the $\mathrm{Ni}^{2+}$ species enhances its reactivity in incorporation with the free-base porphyrin, $\left[\mathrm{H}_{2} \mathrm{TMPyP}\right]^{4+}$. Similar results have also been observed for $\mathrm{Au}^{3+}$ ion ( $d^{8}$ electronic configuration) towards the $\left[\mathrm{H}_{2} \mathrm{TMPyP}\right]^{4+}{ }^{27}$

\subsection{Observed rate constants $\left(k_{\text {obs }}\right)$ as a function} of the concentration of $\mathrm{Ni}^{2+}$

Kinetics of the incorporation of $\mathrm{Ni}^{2+}$ ion into the $\left[\mathrm{H}_{2} \text { TMPyP }\right]^{4+}$ with a variation of the concentration of $\mathrm{Ni}^{2+}\left(I=0.10 \mathrm{M}, \mathrm{NaNO}_{3}\right.$; $\left.\mathrm{pH} 9.50\right)$ at $25 \pm 1{ }^{\circ} \mathrm{C}$ has also been studied in order to ascertain the formation rate constant for the metalation reaction. The observed rate constants $\left(k_{\text {obs }}\right)$ with a concentration of $\mathrm{Ni}^{2+}$ were

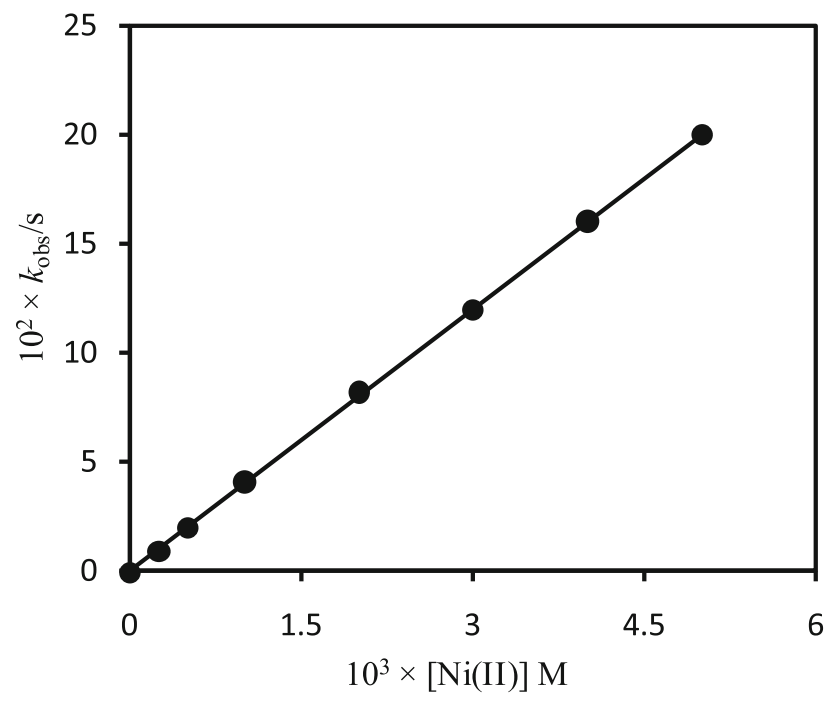

Figure 4. Dependence of the observed rate constants $\left(k_{\text {obs }}\right)$ for the reaction of $\left[\mathrm{H}_{2} \mathrm{TMPyP}\right]^{4+}$ with on the concentration of $\mathrm{Ni}^{2+}$ in $I=0.10 \mathrm{M}\left(\mathrm{NaNO}_{3}\right)$ at $25 \pm 1$ ${ }^{\circ} \mathrm{C} .\left[\mathrm{H}_{2} \mathrm{TMPyP}^{4+}\right]=1.24 \times 10^{-5} \mathrm{M} ; \mathrm{pH}=9.50$. 
obtained by plotting the $\ln \left(A_{\mathrm{t}}-A_{\alpha}\right)$ vs time. The formation rate constant was obtained by plotting the observed rate constants $\left(k_{\mathrm{obs}}\right)$ with the concentration of $\mathrm{Ni}^{2+}$ as depicted in Figure 4. As seen from Figure 4, the rate constant for the metalation reaction increases with increasing the concentration of $\mathrm{Ni}^{2+}$ and passes through the origin $\left(r^{2}=0.999\right)$. This result suggests that the metalation reaction depends on concentrations of both reacting species and follows the first-order kinetics. The formation rate constant $\left(k_{\mathrm{f}}\right)$ for the $\left[\mathrm{Ni}\left(\mathrm{H}_{2} \mathrm{O}\right)_{5}(\mathrm{OH})\right]^{+} /\left[\mathrm{H}_{2} \mathrm{TMPyP}\right]^{4+}$ was found to be 3.99 $\times 10^{-2} \mathrm{M}^{-1} \mathrm{~s}^{-1}$ in $I=0.10 \mathrm{M}\left(\mathrm{NaNO}_{3}\right)$ at $25 \pm 1{ }^{\circ} \mathrm{C}$.

\subsection{Observed rate constants $\left(k_{o b s}\right)$ with ionic strength}

The rate constants of a reaction for opposite charged reacting species decrease as the ionic strength increases while that increase for the same charged species. ${ }^{66}$ Figure 5 shows the dependence of the ionic strength on the rate constants for the reaction between the free-base porphyrin, $\left[\mathrm{H}_{2} \mathrm{TMPyP}\right]^{4+}$, and $\mathrm{Ni}^{2+}$ species in $I=0-10.0 \times 10^{-2} \mathrm{M}\left(\mathrm{NaNO}_{3}\right)$ at $\mathrm{pH} 9.50$ where the experimental conditions were kept constant. The observed rate constants $\left(k_{\text {obs }}\right)$ were obtained by plotting the $\ln \left(A_{\mathrm{t}}-A_{\alpha}\right)$ vs time at different ionic strengths (Figure 5). As seen from Figure 5, the observed rate constants $\left(k_{\text {obs }}\right)$ exponentially decrease with the ionic strengths. These results suggest that the reacting compounds exist as oppositely charged species in solution, however, the speciation diagram is indicating the existence of the monopositive monohydroxo $\mathrm{Ni}^{2+},\left[\mathrm{Ni}\left(\mathrm{H}_{2} \mathrm{O}\right)_{5}(\mathrm{OH})\right]^{+}$, species at solution $\mathrm{pH}$ 9.50. In our previous study, we also found the retardation of the kinetics between the dihydroxo

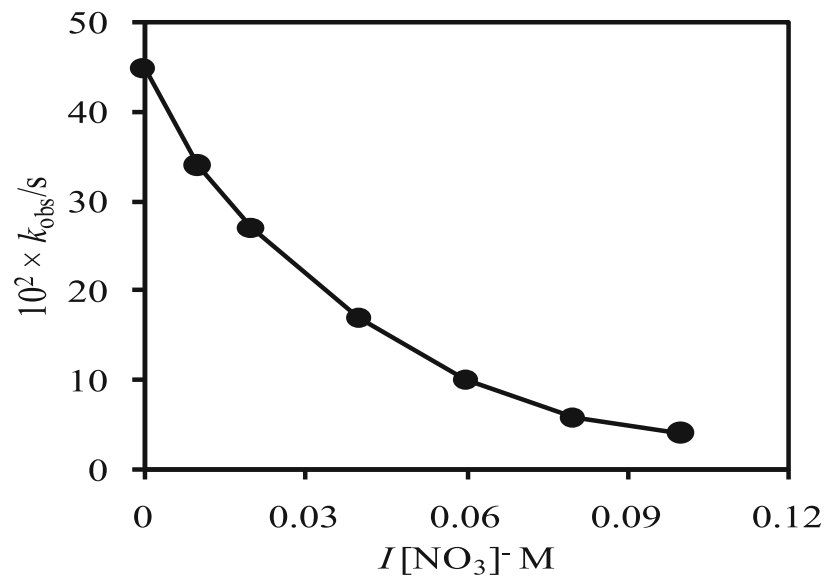

Figure 5. Observed rate constants, $\left(k_{\text {obs }}\right)$, with ionic strengths $\left(\mathrm{NaNO}_{3}\right)$ at $25 \pm 1{ }^{\circ} \mathrm{C}$. $\left[\mathrm{H}_{2} \mathrm{TMPyP}^{4+}\right]=1.24 \times$ $10^{-5} \mathrm{M} ;\left[\mathrm{Ni}^{2+}\right]=1.00 \times 10^{-3} \mathrm{M}$; Solution pH: 9.50 .
$\mathrm{Zn}^{2+},\left[\mathrm{Zn}\left(\mathrm{H}_{2} \mathrm{O}\right)_{4}(\mathrm{OH})_{2}\right]^{0}$, species and $\left[\mathrm{H}_{2} \mathrm{TMPyP}\right]^{4+}$ in the presence of $\mathrm{NaNO}_{3}(I=0.10 \mathrm{M})$ and the net charge of the porphyrin, $\left[\mathrm{H}_{2} \mathrm{TMPyP}\right]^{4+}$, was calculated to be $+3.4 .^{34}$ The rate constants for the incorporation of monohydroxotrichloroaurate(III), $\left[\mathrm{AuCl}_{3}(\mathrm{OH})\right]^{-}$, into the $\left[\mathrm{H}_{2} \mathrm{TMPyP}\right]^{4+}$ also decrease exponentially with ionic strength and the calculated net charge of the free base porphyrin was found to be +3.4 by using the Fuoss equation. ${ }^{27}$ However, in this study, we found a less decreasing tendency of the rate constants as the ionic strength increases. This may be due to the existence of monopositive monohydroxo $\mathrm{Ni}^{2+},\left[\mathrm{Ni}\left(\mathrm{H}_{2} \mathrm{O}\right)_{5}(\mathrm{OH})\right]^{+}$, species in the aqueous solution at $\mathrm{pH} 9.50$ (Figure 2 and Figure 5). Hambright (2002) also reported that the rate constants for the reactions of the $\left[\mathrm{H}_{2} \mathrm{TMPyP}\right]^{4+}$ with $\mathrm{Zn}^{2+}$ species decrease as ionic strength increases, and the apparent net charge of the tetracationic porphyrin was found to be +1.4 on the basis of the Bronsted-Bjerrum equation [Hambright, 2002]. It seems that the direct reaction of the dipositive $\mathrm{Ni}^{2+}$ ion with the $\left[\mathrm{H}_{2} \mathrm{TMPyP}\right]^{4+}$ is strenuous, thus the presence of the nitrate ions causes to reduce the repulsive force between the $\left[\mathrm{Ni}\left(\mathrm{H}_{2}\right.\right.$ $\left.\mathrm{O})_{5}(\mathrm{OH})\right]^{+}$species and the $\left[\mathrm{H}_{2} \mathrm{TMPyP}\right]^{4+}$ by interacting with the positively charged tetracationic porphyrin that facilitates the formation of aggregates of cation-anion with a lower positive charge. Thus, it is assumed that the tetracationic free-base porphyrin, $\left[\mathrm{H}_{2} \mathrm{TMPyP}\right]^{4+}$, carries a relatively lower charge than the actual charge, +4.0 and probably both the monopositive monohydroxo, $\left[\mathrm{Ni}\left(\mathrm{H}_{2} \mathrm{O}\right)_{5}(\mathrm{OH})\right]^{+}$, and neutral dihydroxo, $\left[\mathrm{Ni}\left(\mathrm{H}_{2} \mathrm{O}\right)_{4}(\mathrm{OH})_{2}\right]^{0}$, species of $\mathrm{Ni}^{2+}$

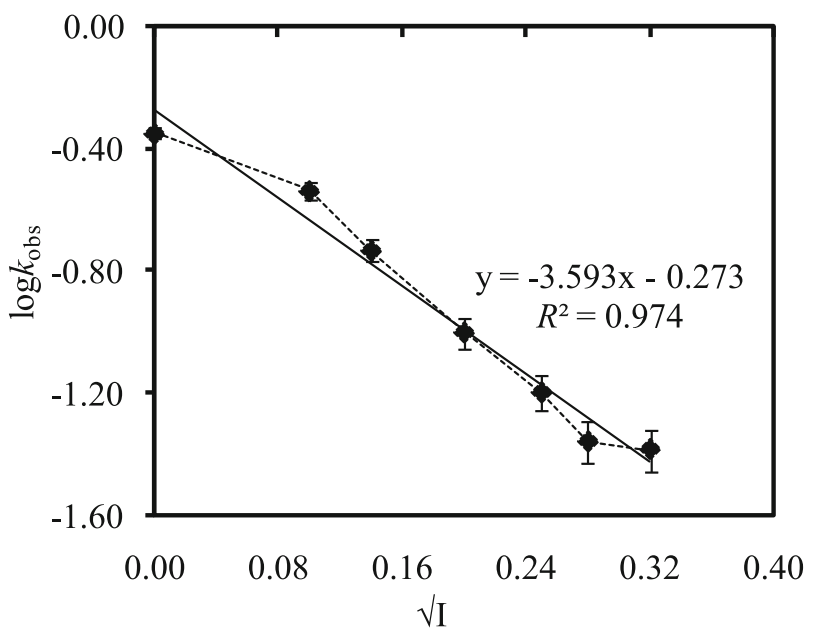

Figure 6. Brønsted-Bjerrum plot for nickel incorporation $\left(1.00 \times 10^{-3} \mathrm{M}\right)$ into positive porphyrin, $\left[\mathrm{H}_{2} \mathrm{TMPyP}\right]^{4+}$, using Debye-Hückel Limiting (DHL) ionic strength function in $\mathrm{NaNO}_{3}$ medium at $25 \pm 1^{\circ} \mathrm{C}$. Error bars represent a variation of $1 \%$. 
ion took part in the reactions with the free-base porphyrin, $\left[\mathrm{H}_{2} \mathrm{TMPyP}^{4+}\right.$, at $\mathrm{pH} 9.50 .^{6,27,34}$

Figure 6 shows the Brønsted-Bjerrum plot for nickel incorporation into the tetracationic porphyrin, $\left[\mathrm{H}_{2-}\right.$ $\mathrm{TMPyP}^{4+}$, where Debye-Hückel Limiting (DHL) ionic strength function was applied. As seen from Figure 6, regression coefficient $\left(R^{2}\right)$, error bars and slope for the plot are $0.974,1 \%$ and -3.59 , respectively. It is expected that the intercept for the plot of $\log k_{\text {obs }}$ vs $\sqrt{ } I$ should be zero, however, that is observed as -0.273 . This is because of the presence of inherent ions that cause intrinsic ionic strength. Nwaeme and Hambright (1984) studied the effects of ionic strength on the rate of the reactions for both the positive and negative porphyrins with divalent metal ions. ${ }^{67}$ They reported that the rates of the reactions for positive porphyrins with positive divalent metal ions increase as increasing the ionic strength and that decrease for oppositely charged reacting species with the ionic strength. Williams et al. (1979) also reported the anionic effect on the reaction rate for tetracationic porphyrins in detergent solution. ${ }^{68}$

According to the speciation diagram (Figure 2), the predominant species of $\mathrm{Ni}^{2+}$ is monopositive monohydroxo, $\left[\mathrm{Ni}\left(\mathrm{H}_{2} \mathrm{O}\right)_{5}(\mathrm{OH})\right]^{+}$, at solution $\mathrm{pH}$ 9.50. Thus, the rate of reaction of the tetracationic tetrakis $(\mathrm{N}$ methylpyridium-4-yl)porphyrin, $\left[\mathrm{H}_{2} \mathrm{TMPyP}\right]^{4+}$, with the monopositive monohydroxonickel(II), $\left[\mathrm{Ni}\left(\mathrm{H}_{2-}\right.\right.$ $\left.\mathrm{O})_{5}(\mathrm{OH})\right]^{+}$, species should be increased with increasing the ionic strength, however, that decreases as a function of ionic strength (Figure 5). These results are suggesting the presence of anionic species of $\mathrm{Ni}^{2+}$ under the experimental conditions, however, speciation diagram (Figure 2) shows the presence of monopositive monohydroxo, $\left[\mathrm{Ni}_{(}\left(\mathrm{H}_{2} \mathrm{O}\right)_{5}(\mathrm{OH})\right]^{+}$, species at solution $\mathrm{pH}$ 9.50. The monopositive $\mathrm{Ni}^{2+}$ species, $\left[\mathrm{Ni}\left(\mathrm{H}_{2} \mathrm{O}\right)_{5}(\mathrm{OH})\right]^{+}$, may associate with the inherent anion, thus forms negatively charged inner sphere reacting species in character such as $\left(\left[\mathrm{Ni}\left(\mathrm{H}_{2}\right.\right.\right.$ $\left.\mathrm{O})_{5}(\mathrm{OH})\right]^{+}$-inherent anion)- ${ }^{-63,69}$ The addition of nitrate ion reduces the positive charge of the cationic porphyrin at the transition state through the formation of anion-cation-porphyrin adducts that causes the decreasing reaction rates for negatively charged nickel species. $^{21,63,70}$

\subsection{Interaction of $[\mathrm{Ni}(\mathrm{II}) \mathrm{TMPyP}]^{4+}$ complex and $\left[\mathrm{H}_{2} \mathrm{TMP} \mathrm{PP}\right]^{4+}$ with DNA}

Figures $7 \mathrm{a}$ and $\mathrm{b}$ show the UV-vis spectral change of the $[\mathrm{Ni}(\mathrm{II}) \mathrm{TMPyP}]^{4+}$ complex and the free base porphyrin, $\left[\mathrm{H}_{2} \mathrm{TMPyP}\right]^{4+}$, upon addition of DNA, respectively. As seen from Figure 7a, a small hypochromicity $(\sim 13 \%)$ at $\lambda=436 \mathrm{~nm}\left(\lambda_{\max }\right.$ of $\left.[\mathrm{Ni}(\mathrm{II}) \mathrm{TMPyP}]^{4+}\right)$ and a very small Bathochromic shift $(\Delta \lambda=\sim 1 \mathrm{~nm})$ were observed upon addition of DNA within a range from 0 to $7.96 \times 10^{-6} \mathrm{M}$ base pairs into the $[\mathrm{Ni}(\mathrm{II}) \mathrm{TMPyP}]^{4+}$ solution. However, the free-base porphyrin, $\left[\mathrm{H}_{2} \mathrm{TMPyP}\right]^{4+}$, displayed a substantial hypochromicity $(\sim 31 \%)$ at $422 \mathrm{~nm}\left(\lambda_{\max }\right.$ of $\left[\mathrm{H}_{2} \mathrm{TMPyP}^{4+}\right)$ and a wide Bathochromic shift $(\Delta \lambda=$ $17 \mathrm{~nm})$ upon addition of the same DNA concentration (0 to $7.96 \times 10^{-6} \mathrm{M}$ base pairs) (Figure $6 \mathrm{~b}$ ).

A fluorescence spectrophotometer was also used in order to investigate the interactions of the $[\mathrm{Ni}(\mathrm{II}) \mathrm{TMPyP}]^{4+}$ and the $\left[\mathrm{H}_{2} \mathrm{TMPyP}\right]^{4+}$ with DNA (Figure S2, Supplementary Information). As seen from Figure S2a, Supplementary Information $[\mathrm{Ni}(\mathrm{II}) \mathrm{TMPyP}]^{4+}$ complex exhibited a weak excitation fluorescence spectrum centered at $633 \mathrm{~nm}$ while the free-base porphyrin, $\left[\mathrm{H}_{2} \mathrm{TMPyP}\right]^{4+}$, showed high excitation fluorescence spectrum centered at $660 \mathrm{~nm}$ with a hump at $\sim 628 \mathrm{~nm}$ in the absence of DNA (Figure S2b, Supplementary Information). The heavy atom effect by the nickel causes weak intensity for the $[\mathrm{Ni}(\mathrm{II}) \mathrm{TMPyP}]^{4+}$ complex. In our previous study, we also found weak intensities from the $\mathrm{Ru}^{2+}, \mathrm{Pd}^{2+}$, $\mathrm{Pt}^{2+}$ - and $[\mathrm{Au}(\mathrm{III}) \mathrm{TMPyP}]^{5+}$ porphyrins in an aqueous solution because of the heavy atom effect. ${ }^{45,46}$

The fluorescence intensity for the $[\mathrm{Ni}(\mathrm{II}) \mathrm{TMPyP}]^{4+}$ complex is significantly decreased upon addition of a low concentration of DNA, and then increased with further addition of DNA (Figure S2a, Supplementary Information). The porphyrin molecules aggregate on the negatively charged phosphate network of the DNA molecules through self-stacking in the presence of a low concentration of DNA, however, de-aggregation occurs upon the addition of additional DNA. This causes the increasing the fluorescence intensity of the metalloporphyrin. ${ }^{45,46}$

On the other hand, the intensity of the fluorescence centered at $660 \mathrm{~nm}$ did not change but the intensity of the hump appeared at $\sim 628 \mathrm{~nm}$ is increased with a low concentration of DNA into the $\left[\mathrm{H}_{2} \mathrm{TMPyP}\right]^{4+}$ solution. The intensity of the hump increases with the addition of DNA and the fluorescence spectrum is finally centered at $630 \mathrm{~nm}$ (Figure S2b, Supplementary Information). These results suggested that the cationic free base porphyrin initially interacts with DNA via a negatively charged phosphate network in the presence of a low concentration of DNA, and then de-stacking occurs upon further addition of DNA. ${ }^{45,46}$ From the UV-vis and fluorescence spectral results, it is confirmed that both the metalloporphyrin, $[\mathrm{Ni}(\mathrm{II}) \mathrm{TMPyP}]^{4+}$, and the free base porphyrin interact 

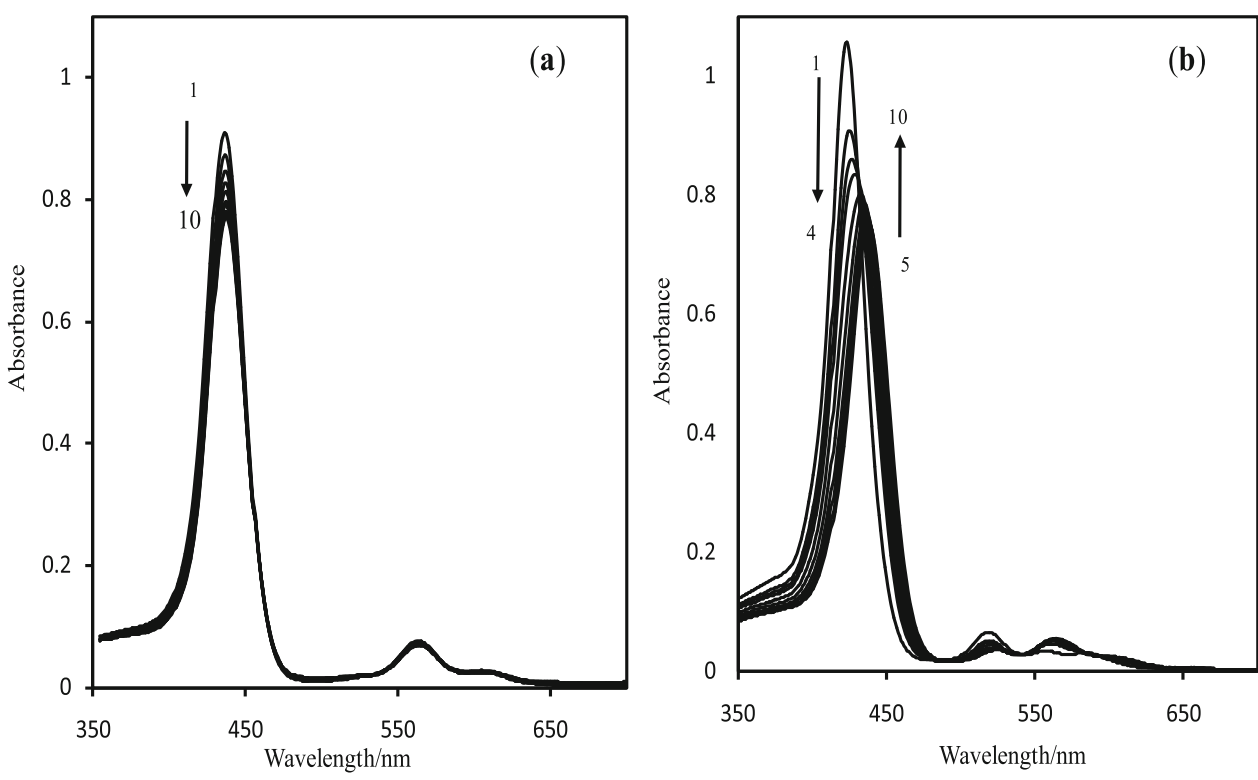

Figure 7. Changes in UV-vis spectra of (a) $[\mathrm{Ni}(\mathrm{II}) \mathrm{TMPyP}]^{4+}$ and (b) $\left[\mathrm{H}_{2} \mathrm{TMPyP}\right]^{4+}$ in the presence of DNA of (1) 0 , (2) 0.56 (3)1.12, (4) 3.33, (5) 4.43, (6) 5.52, (7) 6.06, (8) 6.88, (9) 7.42, (10) $7.96 \times 10^{-6} \mathrm{M}$ base pairs at pH 7.40 (HEPES). Total concentration of porphyrin is $1.14 \times 10^{-5} \mathrm{M}$. Cell path length is $10 \mathrm{~mm}$.

with DNA but their modes of interaction are different. As seen from Figure $6 a$, the hypochromicity and Bathochromic shift $(\Delta \lambda)$ for the $[\mathrm{Ni}(\mathrm{II}) \mathrm{TMPyP}]^{4+}$ are only $\sim 13 \%$ (at $\lambda_{\max } 436 \mathrm{~nm}$ ) and $\sim 1 \mathrm{~nm}$ upon addition of high concentration of DNA, respectively. These results suggested that $[\mathrm{Ni}(\mathrm{II}) \mathrm{TMPyP}]^{4+}$ interacts with DNA via outside binding with self-stacking. ${ }^{41-46}$ However, the significant hypochromicity $(\sim$ $31 \%$ at $422 \mathrm{~nm})$ and a wide Bathochromic shift $(\Delta \lambda=$ $17 \mathrm{~nm}$ ) for the free base porphyrin upon addition of the same amount of DNA confirm its interaction with DNA through intercalation. ${ }^{41-46}$ The presence of metal ion in the porphyrin core is responsible for carrying water molecules as axial ligands that make the bulkiness of the metalloporphyrin molecules. The large size of the metalloporphyrin molecules interact with DNA via outside binding rather than intercalation, however, the free base porphyrin interacts with DNA via intercalation because of its smaller size that facilitates easy excess into the DNA grooves. Metalloporphyrins that are outside binders have catalytic effects to cleave DNA, ${ }^{45,46,71,72}$ thus it is expected that the $[\mathrm{Ni}(\mathrm{II}) \mathrm{TMPyP}]^{4+}$ complex can be used as a chemotherapeutic agent in the medical as well as in the biological fields.

\section{Conclusions}

In this work, kinetics and mechanism of formation of $[\mathrm{Ni}(\mathrm{II}) \mathrm{TMPyP}]^{4+}$ have been studied at $25 \pm 1^{\circ} \mathrm{C}$ in $I=$ $0.10 \mathrm{M}\left(\mathrm{NaNO}_{3}\right)$ within a $\mathrm{pH}$ range from 2.97 to 11.40 in an aqueous medium. Speciation of $\mathrm{Ni}^{2+}$ ions in an aqueous medium has also been done in $0.10 \mathrm{M} \mathrm{NaNO}_{3}$ in order to provide the distribution of the $\mathrm{Ni}^{2+}$ species as a function of solution $\mathrm{pH}$ for the kinetic study. The experimental data have been compared with the speciation diagram generated from the values of hydrolysis constants of $\mathrm{Ni}^{2+}$ ion. The speciation data exhibited the stepwise formation of $\left[\mathrm{Ni}\left(\mathrm{H}_{2} \mathrm{O}\right)_{6}\right.$ $\left.n(\mathrm{OH})_{n}\right]^{2-n}$ species as a function of solution $\mathrm{pH}$. Kinetic studies showed that aqua-monohydroxo, $\left[\mathrm{Ni}\left(\mathrm{H}_{2} \mathrm{O}\right)_{5}(\mathrm{OH})\right]^{+}$, species showed the highest reactivity towards the free-base porphyrin, $\left[\mathrm{H}_{2} \mathrm{TMPyP}\right]^{4+}$. The formation of hydrogen bonding between the oxygen atom of the hydroxo-ligand of the $\left[\mathrm{Ni}\left(\mathrm{H}_{2}\right.\right.$ $\left.\mathrm{O})_{5}(\mathrm{OH})\right]^{+}$species and the pyrrolic hydrogen atom of the $\left[\mathrm{H}_{2} \mathrm{TMPyP}\right]^{4+}$ enhances the reactivity of the aqumonohydroxonickel(II) species. Ionic strength effect on the reaction rate is suggested that the tetracationic porphyrin carries a charge less than +4.0 . It has been expected that the rate of incorporation of the $\left[\mathrm{Ni}\left(\mathrm{H}_{2}\right.\right.$ O) $\left.{ }_{5}(\mathrm{OH})\right]^{+}$species into the $\left[\mathrm{H}_{2} \mathrm{TMPyP}\right]^{4+}$ would be slow but showed fast. From the UV-Vis and fluorescence spectroscopic results, it is concluded that the $[\mathrm{Ni}(\mathrm{II}) \mathrm{TMPyP}]^{4+}$ complex and $\left[\mathrm{H}_{2} \mathrm{TMPyP}\right]^{4+}$ interact with DNA where UV-Vis data suggested that the metallo-complex follows outside binding with selfstacking with DNA while the free base porphyrin shows intercalation. An investigation of the application of the $[\mathrm{Ni}(\mathrm{II}) \mathrm{TMPyP}]^{4+}$ complex with other metalloprphyrins, for example, $\mathrm{Zn}^{2+}-, \mathrm{Ru}^{2+}{ }_{-}, \mathrm{Pt}^{2+}$, $[\mathrm{Au}(\mathrm{III}) \mathrm{TMPyP}]^{5+}$ as anti-COVID-19 agents are now in progress under the international collaboration. 


\section{Supplementary Information (SI)}

Absorption spectra of $\mathrm{Ni}$ (II) in $0.10 \mathrm{M} \mathrm{NaNO}_{3}$ solution at $25 \pm 1{ }^{\circ} \mathrm{C}$ within a $\mathrm{pH}$ range from 2.97 to 11.40 , and fluorescence spectra of $[\mathrm{Ni}(\mathrm{II}) \mathrm{TMPyP}]^{4+}$ and $\left[\mathrm{H}_{2} \mathrm{TMPyP}\right]^{4+}$ in presence of DNA are available at www.ias.ac.in/chemsci.

\section{Acknowledgements}

The authors acknowledge the Ministry of Science and Technology, the People's Republic of Bangladesh for financial support to carry out this work under the project "Photoelectrochemical splitting of water into hydrogen using solar light".

\section{Declarations}

Competing interests The authors declare no competing financial/commercial interest.

\section{References}

1. Pasternack R F and Skowronek W R Jr 1979 Catalysis of the disproportionation of superoxide by metalloporphyrins J. Inorg. Biochem. 11261

2. Marzilli L G 1990 Medical aspects of DNA-Porphyrin Interaction New J. Chem. 14409

3. DeCamp D L, Babé L M, Salto R, Lucich J L, Koo M S, Kahl S B and Craik C S 1992 Specific inhibition of HIV-1 protease by boronated porphyrins $J$. Med. Chem. 353426

4. Batinić-Haberle I, Spasojević I, Hambright P, Benov L, Crumbliss A L and Fridovich I 1999 Relationship among Redox Potentials, Proton Dissociation Constants of Pyrrolic Nitrogens, and in Vivo and in Vitro Superoxide Dismutating Activities of Manganese(III) and Iron(III) Water-Soluble Porphyrins Inorg. Chem. 38 4011

5. Sasaki K, Yumita N, Nishigaki R, Sakata I, Nakajima S and Umemura S I 2001 Pharmacokinetic study of a gallium-porphyrin photo- and sono-sensitizer, ATX-70, in tumor-bearing mice Jpn. J. Cancer Res. 92989

6. Hambright P 2002 In The Porphyrin Handbook K M Kadish, K M Smith and R Guilard (Eds.) (San Diego: Academic Press) p. 163

7. Lin L and Hu J 2008 Inhibition of hepadnavirus reverse transcriptase-epsilon RNA interaction by porphyrin compounds J. Virol. 822305

8. Batinic-Haberle I, Reboucas J and Spasojevic I 2010 Superoxide dismutase mimics: chemistry, pharmacology and therapeutic potential Antioxid. Redox Signal. 13 877

9. Cheng Y, Tsou L K, Cai J, Aya T, Dutschman G E, Gullen E A, et al. 2010 A novel class of meso-tetrakisporphyrin derivatives exhibits potent activities against hepatitis $\mathrm{C}$ virus genotype $1 \mathrm{~b}$ replicons in vitro Antimicrob. Agents Chemother. 54197

10. Guo H, Pan X, Mao R, Zhang X, Wang L, Lu X, et al. 2011 Alkylated Porphyrins Have Broad Antiviral
Activity against Hepadnaviruses, Flaviviruses, Filoviruses, and Arenaviruse Antimicrob. Agents Chemother. 2478

11. Rapozzi V, Zorzet S, Zacchigna M, Pietra E D, Cogoi S and Xodo L E 2014 Anticancer activity of cationic porphyrins in melanoma tumour-bearing mice and mechanistic in vitro studies Mol. Cancer 1375

12. A. Huang H, Song W, Rieffel J and Lovell J F, 2015 Emerging applications of porphyrins in photomedicine Front. Phys. 323

13. Tovmasyan A, Sampaio R S, Boss M K, Bueno-Janice J C, Bader B H, Thomas M, et al. 2015 Anticancer therapeutic potential of $\mathrm{Mn}$ porphyrin/ascorbate system Free Radic. Biol. Med. 891231

14. Varchi G, Foglietta F, Canaparo R, Ballestri M, Arena F, Sotgiu G and Fanti S 2015 Engineered porphyrin loaded core-shell nanoparticles for selective sonodynamic anticancer treatment Nanomed. 103483

15. Su S, Ding Y, Li Y, Wu Y and Nie G 2016 Integration of photothermal therapy and synergistic chemotherapy by a porphyrin self-assembled micelle confers chemosensitivity in triple-negative breast cancer Biomater 80169

16. Malatesti N, Munitic I and Jurak I 2017 Porphyrinbased cationic amphiphilic photosensitisers as potential anticancer, antimicrobial and immunosuppressive agents Biophys. Rev. 9149

17. Batinic-Haberle I, Tovmasyan A and Spasojevic I 2018 Mn Porphyrin-Based Redox-Active Drugs: Differential Effects as Cancer Therapeutics and Protectors of Normal Tissue Against Oxidative Injury Antioxid. Redox Signal. 291691

18. Aggarwal A, Samaroo D, Jovanovic I R, Singh S, Tuz M P and Mackiewicz M R 2019 Porphyrinoid-based photosensitizers for diagnostic and therapeutic applications: An update J. Porphyr. Phthalocyan. 23729

19. Garcia-Sampedro A, Tabero A, Mahamed I and Acedo P 2019 In Multimodal use of the porphyrin TMPyP: From cancer therapy to antimicrobial applications $J$. Porphyr. Phthalocyan. 2311

20. Tebo A, Herrero C and Aukauloo A 2014 In Porphyrins and Metalloporphrins as Components In Artificial Photosynthesis Research K MKadish, K M Smith and R Guilard (Eds.) (Location: World Scientific) pp. 195237

21. Hambright P and Chock P B 1974 Metal-porphyrin interactions. III. Dissociative-interchange mechanism for metal ion incorporation into porphyrin molecules $J$. Am. Chem. Soc. 963123

22. Hambright P 1975 In Porphyrins and Metalloporphyrins K M Smith (Ed.) (Elsevier) pp.233-278

23. Tanaka M 1983 Kinetics of metalloporphyrin formation with particular reference to the metal ion assisted mechanism Pure Appl. Chem. 55151

24. Lavallee D K 1985 Kinetics and mechanisms of metalloporphyrin reactions Coord. Chem. Rev. 6155

25. Funahashi $\mathrm{S}$, Ito $\mathrm{Y}$, Kakito $\mathrm{H}$, Inamo M, Hamada $\mathrm{Y}$ and Tanaka M 1986 Metal ion incorporation into n-methyl5,10,15,20-tetrakis (4-sulfonatophenyl) porphine and its differential rates as applied to the kinetic determination of copper(II) and zinc(II) in serum Microchim. Acta $\mathbf{8 8}$ 33 
26. Tabata M and Tanaka M 1983 Kinetics and mechanism of cadmium(II) ion assisted incorporation of manganese(II) into 5,10,15,20tetrakis(4-sulphonatophenyl)porphyrinate(4-) J. Chem. Soc., Dalton Trans. 1955

27. Habib A, Tabata M and Wu Y 2004 Kinetics and mechanism of gold(III) incorporation into tetrakis(1methylpyridium-4-yl)porphyrin in aqueous solution $J$. Porphyrins Phthalocyanines 81269

28. Almodôvar V A S and Tomé A C 2020 Porphyrindiketopyrrolopyrrole conjugates and related structures: Synthesis, properties and applications J. Porphyr. Phthalocyan. 2443

29. Margerum D W and Cayley G R 1978 In Coordination Chemistry A E Martell (Ed.) (American Chemical Society) pp.1-194

30. Shamim A and Hambright P 1980 Exchange reactions of transition metal ions and labile cadmium porphyrins J. Inorg. Nucl. Chem. 421645

31. Tabata M and Ishimi H 1997 Kinetics and mechanism for the formation and dissociation reactions of 21-(4nitrobenzyl)-5,10,15,20-tetrakis(4-sulfonatophenyl)23H-porphyrinatozinc(II) and-cadmium(II) Bull. Chem. Soc. Jpn. 701353

32. Cabbiness D K and Margerum D 1969 Macrocyclic effect on the stability of copper(II) tetramine complexes J. Am. Chem. Soc. 916540

33. Lavellee D K 1987 In The Chemistry and Biochemistry of N-Substituted Porphyrins (VCH Publishers) pp. 1-313.

34. Habib A, Islam R, Chakraborty M, Serniabad S, Khan M S, Qais D S, et al. 2020 Kinetics and mechanism of incorporation of zinc(II) into tetrakis(1-methylpyridium-4-yl)porphyrin in aqueous solution Arab. J. Chem. 136552

35. Bain-Ackerman M J and Lavallee D K 1979 Kinetics of metal-ion complexation with N-methyltetraphenylporphyrin. Evidence concerning a general mechanism of porphyrin metalation Inorg. Chem. 183358

36. Turay J and Hambright P 1980 Activation parameters and a mechanism for metal-porphyrin formation reactions Inorg. Chem. 19562

37. Sato T, Ebisawa K, Sue $K$, Ito $S$, Saito $T$ and Itoh $N$ 2012 The Kinetics of the incorporation of metals into tetraphenylporphyrin with metal salts in high-temperature water Indust. Eng. Chem. Res. 5113908

38. Peters M K and Herges R 2018 Insertion of Ni(I) into porphyrins at room temperature: preparation of $\mathrm{Ni}(\mathrm{II})-$ porphyrins, and $\mathrm{Ni}(\mathrm{II})$ chlorins and observation of hydroporphyrin intermediates Inorg. Chem. 573177

39. Tan X L, Hu J, Montavon G and Wang X K 2011 Sorption Speciation of Nickel(II) onto Ca-Montmorillonite: Batch, EXAFS Techniques and Modeling Dalton Trans. 41

40. Tian Y, Etschmann B, Liu W, Borg S, Mei Y, Testemale D, et al. 2012 Speciation of nickel(II) chloride complexes in hydrothermal fluids: In situ XAS study Chem. Geolog. 334345

41. Carvlin M J and Fiel R J 1983 Intercalative and nonintercalative binding of large cationic porphyrin ligands to calf thymus DNA Nucl. Acids Res. 116121

42. Dougherty G 1988 Intercalation of tetracationic metalloporphyrins and related compounds into DNA J. Inorg. Biochem. 3495
43. Fiel R J 1989 Porphyrin-nucleic acid interactions: a review J. Biomol. Struc. Dyn. 61259

44. Guliaev A B and Leontis N B 1999 Cationic 5,10,15,20tetrakis(N-methylpyridinium-4-yl)porphyrin fully intercalates at 5'-CG-3' steps of duplex DNA in solution Biochem. 3815425

45. Nyarko E, Hanada N, Habib A and Tabata M 2004 Fluorescence and phosphorescence spectra of $\mathrm{Au}(\mathrm{III})$, $\mathrm{Pt}(\mathrm{II})$ and $\mathrm{Pd}(\mathrm{II})$ porphyrins with DNA at room temperature Inorg. Chim. Acta 357739

46. Habib A, Sarker A K and Tabata M 2014 Interactions of DNA with H2TMPyP4+ and Ru(II)TMPyP4+: Probable Lead Compounds for African Sleeping Sickness Bangla Pharma. J. 1779

47. B. Xu Z B, Yu F Q, Wu F, Zhang H, Wang K and Zhang X L, 2015 Synthesis, DNA photocleavage, singlet oxygen photogeneration and two photon absorption properties of ruthenium-phenanthroline porphyrins $J$. Porphyr. Phthalocyan. 191046

48. Wang M, Mao Z, Kang T-S, Wong C-Y, Mergny J-L, Leung C-H and Ma D-L 2016 Conjugating a groovebinding motif to an $\operatorname{Ir}(\mathrm{iii})$ complex for the enhancement of G-quadruplex probe behavior Chem. Sci. 72516

49. Chao X-J, Tang M, Huang R, Huang C-H, Shao J, Yan Z-Y and Zhu B-Z 2019 Targeted live-cell nuclear delivery of the DNA 'light-switching' $\mathrm{Ru}(\mathrm{II})$ complex via ion-pairing with chlorophenolate counter-anions: the critical role of binding stability and lipophilicity of the ion-pairing complexes Nucl. Acids Res. 4710520

50. Williamson A and Leiros H-KS 2019 Structural intermediates of a DNA-ligase complex illuminate the role of the catalytic metal ion and mechanism of phosphodiester bond formation Nucl. Acids Res. 477147

51. Spence P, Fielden J and Waller Z A E 2020 Beyond solvent exclusion: i-Motif detecting capability and an alternative DNA light-switching mechanism in a ruthenium(II) polypyridyl complex J. Am. Chem. Soc. 142 13856

52. Ptaszynska A A, Trytek M, Borsuk G, Buczek K and Rybicka-Jasin'ska K and Gryko D 2018 Porphyrins inactivate Nosema spp. Microsporidia Sci. Rep. 8 5523

53. Fazaeli Y, Jalilian A R, Amini M M, Aboudzadeh M, Feizi S, Rahiminezhad A and Yousefi K 2013 Preparation, nano purification, quality control and labeling optimization of [64Cu]-5,10,15,20-tetrakis (penta fluoro phenyl) porphyrin complex as a possible imaging agent J. Radioanal. Nucl. Chem. 295255

54. Fazaeli Y, Jalilian A R, Feizi S and Shadanpour N 2013 Development of a radiothallium(III) labeld porphyrin complex as a potential imaging agent Radiochim. Acta 101795

55. Vahidfar N and Jalilian A R 2015 An Overview of Labeled Porphyrin Molecules in Medical Imaging Recent Patents Top. Imag. 53

56. Liu W and Li H 2020 COVID-19 Disease: ORF8 and Surface Glycoprotein Inhibit Heme Metabolism by Binding to Porphyrin ChemRxiv. https://doi.org/10. 26434/chemrxiv.11938173.v2.

57. Cavezzi A, Troiani E and Corrao S 2020 COVID-19: hemoglobin, iron, and hypoxia beyond inflammation. A narrative review Clin. Pract. 101271 
58. Hambright P 2020 In Chemistry of Water Soluble Porphyins K M Kadish, K M Smith and R Guilard (Eds.) (New York: Academic Press) p. 199

59. Baes C F and Mesmer R E 1976 In The Hydrolysis of Cations (New York: Wiley) p. 246.

60. Paquette G and Zador M 1978 Kinetics of interaction of $\mathrm{Zn}$ (II) with hematoporphyrin IX in basic aqueous solution Inorg. Chim. Acta 26 L23

61. Thompson A N and Krishnamurthy M 1979 Peripheral charge effects on the kinetics of $\mathrm{Zn}$ (II)-porphyrin system J. Inorg. Nucl. Chem. 411251

62. Sutter T P G and Hambright P 1993 The effects of peripheral substituents on the kinetics of zinc ion incorporation and acid catalyzed removal from water soluble sulfonated porphyrins J. Coord. Chem. 30317

63. Schneider W 1975 Kinetics and mechanism of metalloporphyrin formation. In Biochemistry. Structure and Bonding (Berlin: Springer). https://doi.org/10.1007/BFb0116551.

64. Pearson R G 1963 Hard and soft acids and bases J. Am. Chem. Soc. 853533

65. Bailey S L and Hambright P 2003 Kinetics of the reactions of divalent copper, zinc, cobalt, and nickel with a deformed water soluble centrally monoprotic porphyrin Inorg. Chim. Acta 34443
66. Castaneda-Agullo M, Del Castillo L M, Whitaker J R and Tappel A L 1961 Effect of ionic strength on the kinetics of trypsin and alpha chymotrypsin J. Gen. Physiol. 441103

67. Nwaeme J and Hambright P 1984 Magnitudes of ionic strength effects in porphyrin metalation and acid solvolysis reactions Inorg. Chem. 231990

68. Williams G, Williams R F X, Lewis A and Hambright P J 1979 Synthesis, characterization and copper incorporation into 5-(4-pyridyl)-10,15,20-triphenylporphyrin Inorg. Nucl. Chem. 4141

69. Longo F 1978 In The Porphyrins D Dolphin (Ed.) (Academic Press) Vol. 5, Ch. 10.

70. Rau W G and Longo F R 1977 Study of the aqueous equilibrium system involving meso-tetrapyridylporphine, alkali metal ions, and hydrogen ions Inorg. Chem. 161372

71. Tabata M, Nakajima K and Nyarko E 2000 Metalloporphyrin mediated DNA cleavage by a low concentration of HaeIII restriction enzyme J. Inorg. Biochem. 78383

72. Habib A, Hara T, Nargis A, Nyarko E and Tabata M 2020 DNA Cleavage and Trypanosomes Death by a Combination of Alamar Blue and Au(III) J. Chem. Soc. Pak. 42141 